\title{
FITTING A VITAL LINKAGE PIECE INTO THE MULTIDIMENSIONAL EMISSIONS-REDUCTION PUZZLE: NONGOVERNMENTAL PATHWAYS TO CONSUMPTION CHANGES IN THE PRC AND THE USA
}

\author{
PETER H. KOEHN \\ Professor of Political Science, University of Montana, Missoula, Montana 59812, USA \\ E-mail:peter.koehn@umontana.edu
}

\begin{abstract}
The United States and China are responsible for nearly 40 per cent of total annual greenhouse gas emissions. Global climatic stabilization cannot succeed without the participation of people and organizations in the PRC and the USA. Given the likelihood of continued political paralysis at the national level in both countries, it is important to assess the strengths, weaknesses, and potential of nongovernmental actors in bringing about durable reductions in GHG emissions. Consumption trajectories present one of the most intractable barriers to anthropogenic GHG-emissions reductions and to long-term climatic stabilization. Nordlund and Garvill's (2003) model is adapted and applied in assessing prospects for value change, specific problem awareness, and sustainable-consumption behavior in the PRC and USA. The contributions of nonstate actors are elucidated when issue bundling (specifically links with stress reduction and healthy futures) and principle bundling are incorporated into the explanatory framework. The involvement of transnationally competent activists in emissionsmitigation projects, value change, and durable sustainable-consumption practices provides a beacon for future possibilities. Chinese transnationals are a key overlooked and underestimated piece in the current emissions-reduction puzzle because of their critical position at the intersection of values, behavior change, and nongovernmental institutions directly and indirectly involved in climaticchange mitigation. Given their special U.S./P.R.C. leverage, other actors concerned with building a sustainable-consumption movement and with climatic stabilization are likely to benefit from devoting increased attention and responsibilities to this group.
\end{abstract}

Efforts to address the challenges of global climatic change cannot succeed without the participation of people and organizations in China and the United States. However, in spite of the growing body of evidence that atmospheric warming poses a serious threat to ecological sustainability and that their populations are the principal contributors to anthropogenic $\mathrm{CO}_{2}$ emissions (U.S., Department of Energy, 2002), ${ }_{1}^{1}$ the governments of China and the United States have been unwilling to take decisive steps to reduce greenhouse-gas (GHG) emissions (see Koehn, forthcoming). The George W. Bush Administration has declined to embrace the emissions-reduction agreements reached in Bonn in 2001 and later formally adopted in Marrakech. In explaining executive-branch opposition to the mandatory compliance targets, President Bush emphasized that "for America, complying with those [Kyoto] mandates would have a negative economic impact" (Bush, 2001, pp. 546-547). Although China has ratified and signed the Kyoto Protocol, the Government of the PRC also has refused to make concrete binding emissions commitments and views national 
stability as dependent upon rapid and relatively unfettered economic growth. Moreover, the extent of U.S./China intergovernmental cooperation on emissionsmitigation projects has been "disappointingly low" (Economy, 2004, p. 192).

Together, the United States and China are responsible for nearly 40 per cent of total annual greenhouse-gas emissions (Zhang, 2000, pp. 739-740). Given the central role of the PRC and the USA in global-warming trajectories ${ }^{2}$ and the emissions reductions that 55 industrialized countries (including Russia) have committed to by 2012, the business-as-usual combustion/consumption behavior of the U.S. and Mainland China populations will account for even greater effect in the future. In the face of political paralysis at the national level in both the USA and the PRC, therefore, prospects for effective actions that will address the Twenty-first Century interdependence challenge of climatic stabilization currently rest on nongovernmental actions and collaborations.

\section{Nonstate Actors: A Key Linkage Piece in the Emissions-reduction Puzzle}

Led by the pioneering work of James N. Rosenau (e.g., 1997a), political scientists have demonstrated that nongovernmental, or nonstate, actors (persons acting individually and through organizations) can play decisive roles in shaping domestic and international policies and projects. The rising domestic and international influence of nonstate actors is a core interest in the contemporary study of global environmental politics (Keck and Sikkink, 1998; Lipschutz and Mayer, 1996, pp. 51, 57, 77). In the post-Rio world, transnationally networked nonstate actors no longer wait for governments to accept and implement international agreements or to reform national policy (see Wapner, 1998, p. 287; Litfin, 1999, pp. 371-372). Among their environmental-protection initiatives, nongovernmental actors are involved in addressing the social, cultural, and other contextual influences that shape householdconsumption practices (see Murphy, 2001, pp. 47, 49).

The argument developed here holds that assessments of the climatic-system impact of the United States and the China Mainland need to take into account the strengths, weaknesses, and potential of national and transnational nonstate actors in helping to control GHG emissions in a time of central government inaction and stalemate. This bubble-up perspective presents a sharp contrast to prevailing approaches to changing population behavior, which emphasize a state-directed, typically regulatory-policy, indirect emphasis (Murphy, 2001, pp. 39, 49; Vincent and Panayotou, 1997, p. 55; Princen et al., 2002, p. 5) and/or continue to portray consumption as "an economic activity that can be adjusted through the application of top-down modifications in market mechanisms" (Cohen, 2001, p. 28). The top-down approach, which rests upon discredited assumptions about responses to information campaigns and price signals (Cohen, 2001, p. 33; also see Stern et al., 1997, p. 136) as well as state regulatory capacity that has been drastically diminished by extensive privatization of power (Conca, 2002, pp. 146, 148-149), has not been effective. 
Whereas the role of individuals is downplayed or abruptly dismissed in most discussions of climatic stabilization, ${ }^{3}$ we are particularly concerned here with personal involvement (Wilson, 2003, p. 26; Barr, 2002, pp. 170, 175) in "private-sphere environmentalism" and in guiding the energy- and materials-intensity decisions and practices of nongovernmental organizations. Private-sphere behavior involves decisions regarding "the purchase, use, and disposal of personal and household products [e.g., automobiles, household appliances, home energy] that have environmental impact" (Stern, 2000, pp. 409-410, 421; Stern, 1997, p. 18). This inquiry focuses on the role of nonstate intermediaries in initiating and supporting innovative emissions-mitigation projects, changing value orientations, and promoting sustainable-consumption behavior.

Broadly speaking, scholars have identified two types of individual and NGO participants in decisions that directly and indirectly affect local and global ecosystems. The first set of influential nonstate actors are homeland-situated citizens and indigenous NGOs. Paul Steinberg (2003, p. 17) refers to the "cosmopolitan nationals" who drive this group as "bilateral activists" and focuses on the critical role they can play in shaping environmental policy in developing countries. Although they are locally based and domestically centered, bilateral national activists ${ }^{4}$ simultaneously participate in international science, policy, and finance arenas. Their greatest asset is the ability to mobilize domestic political resources. We are particularly interested here in the role of bilateral national activists in the China Mainland and the United States with regard to GHG-emissions-mitigation policy/projects and related population values and behavior.

The second set of nongovernmental actors of interest in connection with emissions mitigation in the PRC and USA are the transnational activists who operate both personally and collectively across nation-state borders. Transnational activists specialize in linking external and domestic resources. They are distinguished from Steinberg's bilateral national activists by their dual-/multisociety spheres of operation and sustenance (Vertovec, 2003, p. 641), direct action/project-implementation interests, and transnational identification (some even possessing dual or multiple citizenship). The foremost asset of the transnational activist is transnational competence (TC). TC involves analytic, emotional, creative, communicative, and functional (task) skills (see Koehn and Rosenau, 2002) and is valuable in variety of professional capacities (see, for instance, Koehn 2004a). Transmigrants, a particularly competent subset of transnational actors who continuously move across national borders and maintain extensive contacts with persons in places of origin and reception, are increasing in number and influence in this age of mobility. Transmigrants are plugged into elaborate formal and informal transnational social networks built upon interpersonal bonds of trust with kin, colleagues, and friends. They possess access to many of same political resources in their place of origin that are available to national activists by virtue of ethnic ties, frequent presence over the long term in the original sending society, "process expertise" - understanding of local political culture, bureaucratic rules, the history of conflicts and coalitions, 
likely sources of support and resistance - and astuteness in translating and "fitting" insights garnered abroad in ways that are compelling domestically. Transmigrants, like national activists, have a keen sense of "what 'sells,' what does not, and why" (Steinberg, 2001, pp. 16-17, 146-149, 173, 183).

Although the importance of transmigration is gaining recognition among social scientists, the prospect that transnational migrants and their descendants can act as an influential force for environmental gain in both sending and receiving societies has been overlooked or underestimated by scholars of international relations. This article devotes special attention to the strategic importance of Chinese transnational activists in the challenge of global climatic stabilization.

\subsection{CONTEMPORARY CHINESE TRANSNATIONALS}

By the turn of the millennium, perhaps 50 million Chinese people lived in North America, Southeast Asia, and Europe. Based on 2000 census figures and rough estimates of unsurveyed undocumented migrants, one can project that about 3 million people of Chinese descent lived in the United States alone in 2004. Migration continues, and many Chinese overseas are constantly in motion - both physically and virtually - back and forth among host and origin societies. As Haiming Liu (2002, p. 15) shows, the contemporary Chinese trans-Pacific experience "involves prolonged, complicated, transnational circular migration." Transmigration requires, and facilitates the expansion of, "transcultural capital" - that is, networks and personal contacts that cross national boundaries - as well as understanding of and empathy with people and conditions in sending (origin) and receiving places. Although most are settled members of a U.S. community (see Yang, 1999, pp. 72, 8586), Chinese Americans actively participate in a variety of transboundary economic activities and civil-society forums (see Koehn and Yin, 2002). For many Chinese overseas, participation in transnational sociocultural networks provides an empowering response to discriminatory laws and practices. Successful networking enables transmigrants to resist marginalization in receiving and sending societies.

Many Chinese overseas are bicultural or multicultural. Nearly two-thirds of today's Chinese American population were born in Asia. Their awareness of developments in China is sustained by physical return to, and/or by paying close attention to events in, the Mainland, Hong Kong, and Taiwan. The constant among Chinese transnational families has long been their bilocal or multilocal focus. What is new revolves around the qualitatively and quantitatively enhanced opportunities "for maintaining regular physical contact" among their split components (Ho et al., 2001, p. 25). Available survey data (see Koehn, 2002, p. 238; Lien, 2003, pp. 8-10, 29-30) indicate that large numbers of Chinese Americans use Mandarin and English and are reasonably fluent in both, are aware of and empathize with Mainland conditions and problems, are highly educated ${ }^{5}$ and professionally employed, interact socially and professionally with mainstream Americans and socially with Mainland 
Chinese nationals, maintain annual contact with at least one individual in the PRC, are self-confident about participating in the two societies, and are able to function comfortably on both sides of the Pacific. In short, a high proportion of the Chinese American population are transnationally competent. ${ }^{6}$

In terms of the ability to influence policy, values, and behavior in the PRC and USA, the unique TC skills of Chinese transnational activists are enhanced by the networks they are connected with and the special linking roles they fill. With close ties to the world's principal sources of human-induced global warming, Chinese Americans with a wide range of professional backgrounds occupy a special vantage point from which to identify and carry out effective strategies of transmitting and exerting influence over climatically relevant values and practices in places of origin and residence (see Rosenau, 2003, p. 67). Successful involvement in transnational cross-cutting networks provides a respected foundation for the performance of change-inspiring roles (see Levitt, 2001, pp. 63-64). In contemporary China, the messages conveyed by family members, scientists, and professionals from overseas are highly regarded by consumers, cultural leaders, national activists, and decision makers who influence GHG-emission outcomes. Moreover, the insights and contributions of highly educated and biculturally competent Chinese transnationals are taken seriously in the United States - especially at local ${ }^{7}$ and state levels and within the scientific community where they are disproportionately represented among the new generation of U.S. researchers (see Li, 2002, pp. 28, 32; Wang, 2002, pp. 208; Peng, 2002, p. 432).

\section{Projects, Values, and Behavior}

It is not possible at present to derive reliable estimates of the full impact of national and transnational activists on global consumption and GHG-emissions trajectories. The scope and complexity of relevant interactions is too vast to survey and the possible confounding factors defy control (see Stern, 2000, p. 421). These limitations should not arrest inquiry, however. It is important at this time of political impasse in the principal current and projected emitting states to ascertain whether national and transnational activists are making some headway in shaping behavior of consequence for global climatic change and to appreciate the potential power of their interventions as a linking piece in the multidimensional emissions-reduction puzzle. With this modest goal in mind, the exploration presented here involves three distinct, but interrelated and interculturally informed, levels of analysis. We first consider the role of nonstate actors in projects that promise to mitigate GHG emissions in China and the United States. The next section of the article explores value-change patterns and prospects within the two populations that are the focus of attention. This discussion is followed by analysis of the involvement of national and transnational activists in bringing about sustainable behavior change in the China Mainland and the United States. 


\subsection{EMISSIONS-MITIGATION PROJECTS}

The importance of project analysis has been demonstrated by studies in sustainable international development. Although typically narrower in scope, more sitespecific, more autonomous of the state (Lipschutz and Mayer, 1996, p. 58), and less visible than policies, projects offer concrete evidence of the presence or absence of new directions in collective activity. Nongovernmental actors have assumed responsibility for a wide diversity of international development projects - particularly in the environmental-protection and resource-conservation areas.

Internally, the PRC now embraces thousands of scientists and technicians engaged in environmental research and students enrolled in domestic environmentalstudies programs. The number of formal and informal environmental NGOs and GONGOs (government-organized NGOs) active in the Mainland is rapidly expanding (see Ho, 2001, pp. 901-914; Wu, 2002). Many domestic organizations and politically savvy national activists involved in environmental work already are linked to INGOs (international NGOs), foreign firms and/or universities, and overseas individuals through projects aimed at reducing greenhouse-gas emissions (Koehn, 2004b, pp. 385-390; Economy, 2004, p. 166). National activists affiliated with NGOs and GONGOs in the PRC gain from the visible support and pressure that respected transnationals apply to counter bureaucratic and political resistance within China. Today, largely as a result of the substantial impact of transnational epistemic actors, "the Chinese scientific community almost universally considers working on global change topics to be a challenge, an opportunity, and, given China's vulnerability to climatic disasters, a responsibility" (Committee, 1992, p. 120; Economy, 2001, p. 250).

Although external "coupling institutions" (Steinberg, 2001, p. 178) have succeeded in bringing together transnational and national activists, many INGO staff encounter difficulties realizing project objectives in the PRC due to "language problems and lack of familiarity with China's culture and political system" (Baldinger and Turner, 2002, p. 50). Chinese transnational activists are familiar with the local cultural context, possess process expertise and confidence, and are adept at identifying suitable, respected, and reliable local partners. These skills, which have proven valuable in joint business ventures, scientific collaboration, and a wide range of philanthropic undertakings (Yin, 2005; Wang, 2002, p. 227), enable Chinese overseas to play a valuable role by teaming up with national and other transnational nonstate actors (or local governments) engaged in, or contemplating involvement in, climatic-stabilization projects with replication potential across China (Chen and Uitto, 2003, p. 77).

At least three types of projects are conducive to transnational nongovernmental collaboration in reducing GHG emissions. These are energy-efficiency projects, renewable-energy projects, and transportation projects. The role of nongovernmental actors is illustrated here for each type of project (for additional illustrations of emissions-mitigating nonstate transnational projects in China, see Koehn, 2004b). 
According to recently published scenario analysis, projects focused on enduse efficiency improvements and on the replacement of coal by renewable-energy sources promise to reduce China's 2020 business-as-usual GHG emissions by 43 per cent and 23 per cent (Kroeze et al., 2004, p. 55). In the China Mainland, a number of low-cost and even negative-cost opportunities exist to reduce GHG emissions through efficiency gains (see London et al., 1998, pp. 482-484) and nonstate actors are interested in new energy-efficient technologies and approaches. However, domestic personnel with the expertise required for effective participation in emission-mitigation projects remain in short supply (Stockholm Environment Institute, 2002, p. 48). Thus, an expanding number of organizations that attract Chinese-American scientists and engineers have been involved in training China's specialists in the USA and in placing Chinese American experts in Mainland positions (Stone, 1993, p. 350; China Environment Series 6, 2003, p. 249). Other transnational nonstate actors participate in joint ventures with domestically and internationally image-conscious household-appliance firms (Ross, 1998, p. 829). Funding for energy-efficiency projects, including improved building-insulation and appliance standards, is available through "China Sustainable Energy Program" grants to NGOs from the Energy Foundation and the David and Lucile Packard Foundation (www.efchina.org; Ogden and Fong, 2002, p. 6; also see Dong et al., 1998, pp. 127-128). Most energy-efficiency measures that mitigate China's severe urban air-pollution problems coincidently reduce greenhouse-gas emissions (Koehn, 2004b, p. 385).

In terms of renewable-energy projects, transnationals assist with technology transfers and build diagnostic and monitoring capacity on projects designed to assist China's moves to adopt alternatives to coal and petroleum combustion (see Koehn, 1999, pp. 368, 386n; Boudri et al., 2002, pp. 418-423; www.efchina.org). Particularly helpful nonstate initiatives in the Mainland context include the identification and pursuit of approaches and incentives that maximize the introduction of solar power, wind power, small-scale carbon-free hydro-electric facilities (see Nielsen and McElroy, 1998, p. 150), and conversion-efficient fuel cells (Qian, Finamore, and Clegg, 2003, p. 34; Nakicenovic et al., 2000, p. 138). Wind turbines alone offer the prospect of providing a major share of the required energy supply in China (see Koehn, 2004b, p. 386). At a time when state-provided development assistance has stagnated, foreign corporate and foundation investment, particularly by Chinese overseas, is critical in order for such ventures to acquire sufficient operating capital to take off and succeed (see Liang, 2003, p. 15). Nonstate capital flows to developing countries increased roughly five fold in the decade of the 1990s (see Heller and Shukla, 2003, p. 120) and, between 1979 and 1997, Chinese overseas provided nearly 70 per cent of total foreign capital invested in the Mainland (Peng, 2002, p. 432).

As part of the effort to bring about "blue skies over Beijing" by the 2008 Olympics, NGO engineers are assisting with the application of state-of-the-art fuelefficiency technologies in domestic vehicle manufacturing - including systems that 
incorporate fuel cells, electric drive, and batteries (see Ogden and Fong, 2002, p. 7; An, 2003, p. 8; Sperling and Salon, 2002, pp. 17, 19). Among the Olympics-driven transportation initiatives are joint projects undertaken by Tulane University and the Beijing Municipal Government, Tsinghua University's fuel-cell-bus project, the Harvard University/Northern Jiaotong University clean-vehicle research project, and other programs funded in partnership with the Energy Foundation, Packard Foundation, and Hewlett Foundation (see Koehn, 2004b, p. 388). Chinese overseas investors are a promising source of needed venture capital for the development of a hydrogen-infrastructure system (Qian, Finamore, and Clegg, 2003, pp. 38-39).

\subsection{CONSUMPTION VALUES AND BEHAVIOR CHANGE}

Energy-efficiency improvements and technological breakthroughs involving renewable-energy sources and improved product designs are not likely to be sufficient in themselves to result in climatic stabilization (see, for instance, Ash and Edmonds, 1998, p. 874; Ray, 2002, pp. 97-98; Murphy, 2001, pp. 39, 47, 49; Roberts, 2004, p. 301). Indeed, by lowering costs, improved production efficiencies typically result in the transfer of savings into additional materials and energy consumption (i.e., new and increased demand) and overall emissions levels that exceed what existed prior to introduction of the production efficiencies (Manno, 2002, p. 68; also Princen, 2002, p. 26; Kates, 2000, p. 24; Hall, 2004, p. 88; for China-specific evidence, see Sinton and Fridley, 2003). Thus, attention also needs to be devoted to consumption patterns. Agenda 21 broke new ground in the early 1990 s by explicitly acknowledging that unsustainable consumption and production in industrialized states is the major cause of global environmental deterioration and by underscoring the danger that people in developing countries will emulate the damaging lifestyles of those in wealthy nations (see Cohen, 2001, p. 27).

Consumption trajectories present one of the most intractable barriers to anthropogenic GHG-emissions reductions and to long-term climatic stabilization. The relationship of environmentally sensitive values to the adoption of sustainableconsumption behaviors is complex. Although some social-science research indicates that "value orientations are significantly correlated with beliefs about the environmental consequences of human activity..., with intentions to perform pro-environmental acts..., and with self-reported pro-environmental behavior" (Zavestoski, 2001, p. 174; also see Barr, 2002, pp. 28-29; Fazio and Zanna, 1981, pp. 164-165), other studies in environmental psychology indicate that one cannot assume that changes in people's values, as well as education/information by itself, will result in durable changes in individual or collective behavior (see, for instance, Chan, 1998, pp. 318, 325; Bell et al., 2001, pp. 481-482; Chase and Panagopoulos, 1995, p. 69; Blake, 1999, p. 266; Eden, 1996, p. 197; De Young, 1993, pp. 497, 499; Stern, 2000, p. 419). Annika Nordlund and Jorgen Garvill (2003, pp. 341-345) provide a useful and tested model related to personal-car use 
that has broader application in elucidating the U.S. and Mainland China population contexts considered here. Their model posits that both general and ecocentric values shape environmental-problem awareness. Specific environmental problem awareness, in turn, influences the extent to which individuals perceive a moral obligation to act and the presence of this personal norm affects one's willingness to cooperate. In exceptional cases, a direct path exists between specific awareness of the seriousness of an environmental problem and willingness to cooperate.

Although willingness or intention to act is an important antecedent, the realization of actual behavior change is not encompassed by the Nordlund and Garvill model. Three additional factors have been identified as catalysts for widespread and "durable" (see DeYoung, 2000, p. 511) pro-environmental action. They are emulation and social reinforcement (Stern et al., 1997, p. 136; Ajzen and Fishbein, 1980, pp. 6-7; Schultz et al., 1995, p. 114), perceived ease of opportunity (access to time, money, storage space, services) to engage in the action (e.g., recycling) (Tanner, 1999 , p. 154), and perceived likelihood that one's actions will make a difference (Bell et al., 2001, p. 483; Blake, 1999, pp. 264-265; Stern, 2000, pp. 412-415; Barr, 2002, p. 19; Barr et al., 2003, p. 414; Kaplan, 2000, pp. 498-499, 503).

\subsection{CLIMATIC-STABILIZATION VALUES FOR VOLUNTARY ACTION}

Individual and collective actions are shaped by values, or general judgments of what is important or right. Blake (1999, p. 271; also see Barr, 2002, pp. 23-24) notes that different scholars use the terms values, attitudes, concerns, and beliefs and that "constructing fixed categories on the basis of distinctions between these terms is likely to be a confusing and often fruitful exercise." Value orientations that are relevant to consumptive practices include broad and specific subjective attitudes toward life in general and resource use in particular. Value frameworks encompass basic principles and criteria for action that may or may not be deeply held, equally valued (see Stern and Dietz, 1994), and consistent.

General values, specifically altruism/self-transcendence and pro-environment dispositions (ecocentric values), act as amplifiers of information that facilitate specific problem awareness (Nordlund and Garvill, 2003, pp. 344-345; Stern, 2000, p. 414; Bamberg, 2003, p. 23). Therefore, the presence of these general value orientations within the populations of China and the United States can be expected to promote perceptions that global climate change is a serious problem and that unsustainable personal and organizational consumption contributes to the problem. How widespread are these general values? Does specific problem awareness exist?

\subsubsection{Unearthing Buried Treasures: Indigenous Foundations for Sustainable Consumption}

Alan Durning (1992, pp. 145-146) concludes that "even in the United States, now arguably the most wasteful society in human history, thrift and frugality are the 
buried touchstones of the national character.' In support, research conducted by Raymond De Young indicated that a substantial proportion of the small-town residents surveyed in the U.S. midwest derived intrinsic satisfaction from a reduced consumption lifestyle (De Young, 1990/1991, p. 226; also see Durning, 1992, pp. 38-39, 41-43). In the mid-1990s, Willet Kempton, James Boster, and Jennifer Hartley found overwhelming support for protecting the environment even when they explicitly connected this position to a reduced "standard of living today" or to returning to "a less materialistic way of life" (Kempton et al., 1995, pp. 99, 134; also see Stern, 1997, p. 16; Harwood Group, 1995, pp. 1, 5, 10, 17). By the end of the Twentieth Century, frank talk about frugal energy usage and responsible consumption increasingly occurred among nongovernmental actors and many people in the United States - especially young people - embraced attitudes favorable to resource conservation (Princen et al., 2002, pp. 2, 13).

Respect for resource-conservation practices runs deep in traditional Chinese culture (Stockholm Environment Institute, 2002, p. 12). Many Mainland Chinese are acutely aware of the seriousness of China's environmental problems (see Lo and Leung, 2000, pp. 683-685, 691-693, 699; Ferris and Zhang, 2002, p. 549; Stockholm Environment Institute, 2002, p. 50) and still derive considerable personal satisfaction from the frugal use (and reuse) of resources in everyday living. Carlos Lo and Sai Wing Leung (2000, p. 689) report that strong "green values" are widely held at the personal level among residents of Guangzhou - one of China's most industrialized cities. In their 1996 survey, 94 per cent of the respondents agreed or strongly agreed that they ought to conserve electricity; 73 per cent believed that they "ought to buy environmentally friendly products"; 68 per cent valued recycling household waste; and 56 per cent agreed that "to spend more on environmentally friendly products is worthwhile" (also see Madsen, 2000, pp. 316-318; Lu, 2000, p. 141). ${ }^{8}$ Most Chinese also possess modest expectations regarding temperature-comfort levels inside buildings (Dong et al., 1998, pp. 128-129). In short, "Chinese society has not yet cemented a highconsumption pattern ..." (Stockholm Environment Institute, 2002, p. 50) - particularly in rural areas, in interior towns, and among women (Sklair, 1994, pp. 271, 273, 278).

\subsubsection{Value Change and Specific Problem Awareness}

While the cultural and attitudinal foundation for sustainable-resource use exists in both societies, competing orientations and presentations constitute formidable barriers to specific awareness of the threats of current consumption trajectories in terms of climatic change. At present, most residents of the United States, who consumed 24 per cent of the world's energy usage while constituting only 5 per cent of its population in 1990, show little inclination to curtail consumption. Many are affixed to a lifestyle based on relatively cheap fossil-fuel energy, "larger [and warmer] homes, more powerful vehicles, and more electronics and home appliances" (Spray and McGlothlin, 2002, p. 149; Bord et al., 1998, p. 83). 
Across the Pacific, China's boom in luxury housing has propelled increased home-energy usage (Bradsher, 2003, p. A8; Roberts, 2004, p. 156). The ostentatious consumption standards set by wealthy trendsetters "have created new demands for environmentally damaging products" (Oksenberg and Economy, 1998, p. 354). Accession to the World Trade Organization has accelerated access to the estimated 240 million people who belong to China's consumer class (Mayell, 2004) by the global "priests and prophets of the culture of competition and consumption" who have been working arduously to instill the value of "self-expression through consumption of material goods" (Madsen, 1995, pp. 166, 171-172; Andrews, 2005, pp. C1, C5; Sklair, 1994, pp. 260-261, 268-269). Many Mainland Chinese, at 22 per cent of the world's population but using only 8.5 per cent of its energy in 1990 , aspire to spend newly acquired disposable income on consumables such as longdenied electrical appliances, motorized transport, heating and air conditioning (see Koehn, 2004b, p. 389; Ogden and Fong, 2002, p. 7; Sklair, 1994, pp. 263-264). In terms of its national consumption trajectory, China faces the further challenge of addressing the complex factors that affect reproductive values.

What specific awareness breakthroughs are conducive to reductions in emissions-generating consumption? In today's global economy, contextualized understanding of the upstream and downstream emission ramifications of one's consumption decisions is obscured by "distancing" - that is, "the severing of ecological and social feedback as decision points along the chain are increasingly separated" by geography, culture, class, and power (Princen, 2002, p. 16; Clapp, 2002, p. 158; Conca, 2002, pp. 143-144). For instance, "unseen" upstream organizational decisions determine "which products are available for purchase" and "which industrial processes are employed to manufacture them" (Stern, 1997, p. 18). In a downstream example, few Americans demonstrate concern about the distant environmental and health risks associated with massive exports of plastic waste to China (Clapp, 2002, p. 165). In terms of emissions-reducing behavior, therefore, people acting along all nodes of the consumption chain must accept responsibility for transforming upstream (extraction and production) and downstream (waste-disposal) processes in addition to adopting sustainable-use lifestyles (see Princen et al., 2002, pp. 12, 15-17; Clapp, 2002, p. 158; Stern, 1997, pp. 18-19; Conca, 2002, p. 153).

The magnitude of the required population value adjustments required to reverse consumption trajectories in China and the United States should not be underestimated (see O'Brien, 1995, p. 168). ${ }^{9}$ Moreover, given the profound perceptual shifts that are required, available strategies that might promote population value change all possess limitations. Nevertheless, we know that modifications in value orientations are greatly facilitated by convincing proof that failure to change will produce proximate danger (see Rosenau, 1997b, pp. 340-341, 352; Durning, 1992, p. 25; Spray and McGlothlin, 2002, pp. 150, 152). The proof required for value change in a direction conducive to climatic stabilization can be transmitted through intentional and unintentional inputs. Intentional strategies rely upon education and population mobilization via normative appeals. Powerful normative appeals rest on 
compelling legitimating and implementing principles such as "responsibility for one's children and subsequent descendants" or for future generations (Kempton et al., 1995, pp. 12-13, 95-96, 101) and appreciation of the immediate and longterm personal benefits associated with a frugal and simple lifestyle (see De Young, 1990/1991, pp. 215-216, 226; Kempton et al., 1995, pp. 101, 136; Durning, 1992, pp. 137-139, 149). Unintentional inputs include "focusing events" that create a widespread and common sense of urgency - such as extreme climatic occurrences (see Spray and McGlothlin, 2002, p. 150; Rosenau, 2003, pp. 28-32, 216-217, 230-231; Tusiani, 2004, p. A8; Uzzell, 2000, p. 316; Gladwell, 2000, p. 9; Chase and Panagopoulos, 1995, pp. 74-75).

Our focus here is limited to intentional strategies within the reach of national and transnational activists. One cannot expect to find that all transnationals promote sustainable-consumption and anti-commoditization practices..$^{10}$ While national and transnational activists possessing a variety of professional and educational backgrounds have utilized transcontinental migration networks as two-way channels for interpersonally transmitting (Steinberg, 2001, p. 201) and reinforcing energyconservation and sustainable-consumption sensitivities, in other cases the movement of people between the China Mainland and the USA has "transformed lower consumers into higher consumers. . . [who] then transfer these values and aspirations back to their places of origin during their periodic returns to home areas" (Skeldon, 1997, p. 211). Moreover, individuals find different values useful in different situations (O'Brien, 1995, p. 167; Chase and Panagopoulos, 1995, p. 71). Rather than attempting to assess the net impact of transmigration on consumption patterns, what is central to this more modest analysis is identification of the diverse alternative transnational pathways to value change that facilitate growth in specific problem awareness in China and the United States. Are there missing ingredients that would make sustainable consumption more compelling among both populations?

\subsubsection{Transnational Pathways to Value Change in China and the United States}

Values derived from direct life experience are more deeply held and predictive of behavior than are abstractly derived values (Fazio and Zanna, 1981, p. 195; Bell et al., 2001, p. 483; Chase and Panagopoulos, 1995, p. 76). As long as the physical signals of global warming are not perceived through direct personal experience, it is difficult to change prevailing values and risk assessments (Bord et al., 1998, p. 78; Shanahan and Carlsson-Kanyama, 2005, p. 300). However, other consequences (e.g., air pollution) that accompany GHG emissions and conspicuous consumption are directly and immediately observable (Macnaghten and Jacobs, 1997, p. 19). Based on results from their "Health of the Planet Survey" conducted in 24 nations, Dunlap et al. (1993, p. 15) conclude that "social science analyses of environmentalism. . have downplayed the role of direct human experience with environmental degradation, which is especially noticeable at the local levels in the poorer nations." Since the negative aspects of natural and social consequences and contributors (see Uzzell, 2000, p. 314) are particularly acute in 
Chinese localities, they are likely to be witnessed by Chinese overseas who possess multilocal ties and attachments. Through their strong social and empathetic bonds (see Lipschutz, 1997, pp. 436-437) and proximate interpersonal interactions (Uzzell, 2000, p. 315) in both societies, Chinese transnationals transform insights based on direct experience with the costs of U.S. and Mainland emissions trajectories into a rich reservoir of tenacious indigenous cultural symbols, images, and positive and negative metaphors that extol the benefits of sustainable development. Weller and Bol $(1998$, pp. 483, 496) show that contemporary Neo-Confucians, who have a following among intellectuals within and outside the Mainland, "easily find an ecological tendency in their tradition ..." and that Chinese cosmic-resonance theory "offers a view of human life that fits well with contemporary environmental science..."

Chinese transnationals also create appealing narratives of resourceful living that respond to Tu Wei-ming's (1991, pp. 10, 14) powerful call for forms of life that are "not only commensurate with human flourishing but also sustainable in ecological and environmental terms." Zuoyue Wang (2002, pp. 217-218) found that the "strongest motivation" among the influential Chinese American scientists who have collaborated on Mainland undertakings is "cultural nationalism." Among many Chinese American professionals and family members, cultural nationalism translates into concern for sustainable development and population health. Chinese transnational activists who are involved in framing and transmitting resourcecurtailment values encounter a receptive audience in China where about 80 per cent of the urban dwellers surveyed by Louis Harris and Associates in 1994 expressed willingness to pay higher taxes and to volunteer their time in exchange for environmental protection (cited in Steinberg, 2001, p. 41; also see Liu, 1998, pp. 592, 595). Particularly fruitful are linkages with China's zhiqing, or Cultural-Revolution, generation, many members of which are disillusioned with materialism and actively pursuing a renewed sense of moral purpose through informal associational activities and cultural actions (Yang, 2003a, pp. 286-289; Weller and Bol, 1998, p. 492).

First-hand participation in an environmental-protection effort is an important predictor of future behavior (Hawthorne and Alabaster, 1999, p. 40). Consequently, the expansion of opportunities to discover and enhance personal efficacy through the learning of effective action strategies and through participation in pro-environment activities constitutes a valuable emissions-reduction strategy (De Young, 1993, p. 488, 493). The multiple and diverse awareness-raising and sustainable-consumption efforts that currently link trusted nonstate transnational activists and environmental NGOs with Mainland bicultural activists include:

- collaboration with the Global Village Environmental Culture Institute on environmental-education initiatives aimed at popularizing reuse and recycling among Beijing households (Stockholm Environment Institute, 2002, p. 89; Ho, 2001, pp. 909-910) 
- support for Chinese university student environmental associations that have identified global warming as their issue of greatest concern (see Lu, 2003, p. 62)

- contributions to the Professional Association of China Environmentalists' on-line journal of topics related to China's environment (China Environmental Forum, 2002, p. 197) ${ }^{11}$ and other internet-based communications (Yang, 2003b)

- participation in the World Wildlife Fund-supported graduate program on the human dimensions of climate change at Tsinghua University (China Environmental Forum, 2003, p. 239)

- support for the Green Ants' "green-life campaign" and the Volunteers Association of Environmental Protection of Yueyang City's efforts to decrease public consumption by promoting "reduce, reevaluate, reuse, recycle, and rescue principles" (China Environmental Forum, 2002, pp. 202, 209; also see Manno, 2002, p. 94)

- participation in the International Awareness Community Theater (I ACT)'s interactive educational program that works with teachers, professional actors, and drama instructors on school and cultural-center performances that engage Chinese students in communicating environmental concerns (China Environmental Forum, 2002, p. 181).

Other promising value-change initiatives would partner Chinese transnationals with NGOs in China and the United States on educational programs designed to raise/reinforce awareness regarding the personal, intergenerational, societal, and environmental virtues and benefits associated with:

- "making purchasing decisions based upon [product] source reduction characteristics of durability, repairability and reusability" (De Young, 1990/1991, p. 221; also see Barr, 2002, p. 11; Ophuls and Boyan, 1992, p. 81; Clapp, 2002, p. 161)

- reproductive reductions (Chandler et al., 2002, pp. 15, 18, 52)

- restraining the ownership and use of personal motor vehicles (Sperling and Salon, 2002, pp. 13-14)

- public and nonmotorized transportation (see Potter, 2001, p. 141; Nordlund and Garvil, 2003, p. 345; Lowe, 1989; O'Riordan and Jordan, 1996, pp. 80-81)

More Chinese Americans live in California than in any other state. Returning Chinese Americans from Los Angeles and Shanghai can speak with authority about the daily struggle with vehicle congestion. Other transnationals residing in California can share information about that state's novel attempt to require automobile manufacturers to cut carbon dioxide and other GHG emissions by 30 per cent within eleven years (Hakim, 2004, p. Al, B3) and their experience with ways of reducing the negative impacts of motorization - such as telecommuting and office decentralization - that are adaptable in the Mainland (see Shen, 1997, p. 603; Mao 
and Chen, 2001, p. 325; O'Riordan and Jager, 1996, p. 357; Kaplan, 2000, p. 501; Stern, 1997, p. 22).

Chinese transnationals can partner with a host of respected and trusted mainstream nongovernmental actors for the promotion of specific awareness building in the USA (Blake, 1999, p. 266). The challenge is formidable. Although some enhancement of conceptual tools is occurring and cultural models that would lead to more effective consumer choices exist, extensive anthropological study led Kempton, Boster, and Hartley $(1995$, pp. 219, 225) to conclude that people in the United States "have serious misunderstandings about global environmental issues, which skew public support for policies for irrelevant reasons." In 1999, only 11 per cent of the respondents interviewed in the United States (and in China) correctly identified the combustion of fossil fuels as the principal anthropogenic source of global warming (Brechin, 2003, p. 219). Moreover, one encounters limited public understanding of the emissions consequences of upstream (extraction and production) and downstream (waste-disposal) processes. Furthermore, while a majority of those polled by Gallop in 2003 personally worried about global warming "a great deal" or "a fair amount," the issue ranked ninth out of ten environmental problems (Brechin, 2003, pp. 112-113; also Bord et al., 1998, pp. 77-78). On the encouraging side of the ledger, over 70 per cent of the U.S. public believes it is "necessary to take immediate steps to counter global warming" (Andrews, 2001, p. A3) and a large majority favors U.S. participation in the Kyoto Protocol (Kull, 2005, pp. 3-5).

Different strategies for encouraging sustainable-consumption values and practices are appropriate and effective in different circumstances. Partnering efforts to legitimate climatic-stabilization narratives will be most effective when they occur at the local level - where, increasingly, members of the Chinese American community are active and trusted ( $\mathrm{Li}, 1999$, p. 21; Watanabe, 2001, pp. 377-378). For instance, personal story telling in schools about the health effects of GHG emissions in China builds sensitivity about climatic change among young people (Stoll-Kleemann et al., 2001, p. 115).

\subsection{ILLUSTRATIVE PATHWAYS TO BEHAVIOR CHANGE}

Both social-science research and cultural analysis confirm that substantial segments of the populations of China and the United States possess a general value orientation that, over time, should promote awareness of the specific problems (GHG-emissions levels, the impact of consumption and transportation practices, and related policy decisions/nondecisions) associated with climatic-system change. Openness to the mutually satisfying possibilities inherent in shared resource-conservation values will extend further among both populations as analytic and conceptual skills expand (Rosenau, 1997, pp. 350-351) and as lay publics increasingly recognize the unsustainability of fossil-fuel-dependent lifestyles and automotive-centered economies (Paterson, 2000, pp. 258-260; Durning, 1992, pp. 82-84; Molloy, 2004, p. A2). 
To date, however, specific problem appreciation is underdeveloped. The disconnect between general population values and specific problem appreciation results from the multiplicity of factors and complexity of the linkages involved in the climatic system, the time-lagged nature of observable consequences, and the lack of clear and consistent signals from political leaders. Consequently, many people remain "woefully uninformed about the nature of global warming and... about the environmental consequences of their individual and collective actions" (Bord et al. 2000, p. 216).

The Nordlund and Garvill model leads us to expect that transnational and national activists who possess specific problem awareness in the climate-change domain are likely to perceive a moral obligation to cooperate in emissions-reducing efforts. They also discovered a direct path for some people from general problem awareness to perceived moral obligation (Nordlund and Garvill, 2003, p. 344). The norm of personal responsibility, in turn, influences willingness to cooperate (Hawthorne and Alabaster, 1999, p. 40). Although fewer Chinese overseas and other nonstate actors are at the willingness-to-cooperate attitudinal stage relative to those holding conducive general values, the numbers are not inconsequential.

Nevertheless, we also know that willingness or inclination to cooperate does not always lead to responsible individual and collective behavior. What does it take to ensure that nonstate actors who are inclined to cooperate actually will engage in voluntary actions that will result in reduced consumption and combustion in the two paramount GHG-emitting societies? Icek Ajzen's (1991) amended theory of planned behavior suggests that "perceived behavioral control," or self-efficacy, also must be present for behavior change to occur (also see Barr, 2002, p. 78; Stern, 2000, p. 413; Hawthorne and Alabaster, 1999, p. 40; Eden, 1993, pp. 1748, 1755). One key dimension of self-efficacy is the availability of a strategy that promises success.

\subsubsection{Issue Bundling: Health, Stress Reduction, Consumptive Behavior, \& Greenhouse Gases}

Given that the perceived personal threat of global warming is relatively low and that few citizens currently demonstrate long-term willingness to curtail consumption practices out of exclusive concern for their climatic impact (Bord et al., 1998, pp. 81,83-84), we also need to explore the promise of issue bundling for nonstate action in the PRC and the USA - that is, tying together the co-benefits of previously distinct public concerns (Steinberg, 2001, p. 203). In general, linking behavior to personal/family health is a proven pathway for motivating personal action (Stern, 2000). Linkages to personal/family health concerns have been successful in bringing about dramatic behavior changes in the recent past with regard to smoking cessation, drinking and driving (see Myers, 1997, p. 54), and asbestos removal (Castleman, 2004).

Coupling consumption practices with health promotion and psychosocial-stress reduction promises to be a particularly powerful strategy for bringing about 
behavioral change in China and the United States. At the individual and organizational levels, the same actions that reduce GHG emissions over the long-term also immediately lower personal stress and dramatically diminish direct and indirect threats to personal and family health (see McQueen et al., 2001, p. 318; Jackson, 2005; McMurray and Smith, 2001, p. 41). In both the USA and the PRC, moreover, reducing emissions from coal-fire plants and vehicles would provide substantial public-health benefits (Cifuentes et al., 2001, pp. 1257-1258; Chiu et al., 2003, p. 44e). Davis et al. (1997, pp. 1341-1342, 1346-1347) estimate that diminished exposure to the particulate matter that is associated with fossil-fuel combustion processes under a GHG-emissions-reduction scenario would avoid 33,000 deaths per year in the USA by 2020 and save far more lives in China. Since the negative health consequences associated with these emissions are proximate and directly and immediately discernable (Bickerstaff and Walker, 2001, pp. 140-143), the health benefits associated with reduced air pollution "could be a strong motivator for GHG mitigation action" (Cifuentes et al., 2001, p. 1259; Baldassare and Katz, 1992; Hobson, 2003, pp. 107-108). With recent studies confirming that hemispheric winds are transporting vast quantities of transpollutants, including fine particulate matter, within days from China's industrialized cities to the U.S. west coast (Missoulian, 23 February 2004, p. A2; Baldinger and Turner, 2002, p. 45), the public-health interests of key segments of both populations would be promoted by emissions reductions.

2.4.1.1. China: Global Hazards and Personal Forbearance. There is ample reason to expect that bundling GHG-emissions reductions and health concerns would influence consumption behavior among Chinese transnational and national activists and the Mainland public. We know that hazard appraisal constitutes a key factor affecting pro-environmental behavior and that how individuals appraise hazards is shaped by "the socio-cultural context in which risks are framed and debated" (Lai et al., 2003, pp. 371, 382). In the Chinese case, subjective risk appraisals are "highly receptive" to the influence of traditional values closely associated with Confucianism and Taoism and to the psychological processes of self-criticism (less omnipotence) and amplification of the interdependent dimension of "self." As a consequence, many Chinese possess a heightened sense of personal vulnerability to psychosocial stressors and health risks and tend to perceive personal vulnerability "simultaneously as a threat to society" (Lai et al., 2003, pp. 371-372, 381). The latter perception facilitates activation of social-altruistic norms that motivate behavior (Stern et al., 1993, p. 324).

In a pertinent environmental-psychology research study set in comparative context, Lai et al. (2003, p. 379) discovered that Hong Kong Chinese find global techno-human hazards particularly threatening. They conclude (p. 381) that, given the emphasis in Chinese culture on self-directed means of coping with life stressors, Chinese are prone to express pro-environment behavior by initiating self-improvement and exercising forbearance rather than by participating in 
an environmental movement. It is not surprising, then, that the items De Young (1990/1991, p. 222) uses to operationalize frugality ("keeping things running past normal life," "finding ways to avoid waste," "repairing rather than throwing away," "saving things I might need someday," and "finding ways to use things over and over") continue to be widely practiced in China. Among China's vast middleconsumption stratum, one finds a rich array of norms and practices that can serve as models for sustainable livelihoods (see Conca, 2002, pp. 150-151).

\subsubsection{USA: Consumption Efficiency, Stress Reduction, and Intrinsic Satisfaction.}

From a behavioral standpoint, durable voluntary reductions in emissions-generating consumption rarely occur in the United States in the absence of issue bundling. Although they tend to secure little media attention and often are difficult to assess, collective and increasingly networked efforts that link reduced consumption to other motivators abound (Maniates, 2002b, pp. 202, 212-213, 226-227; Kaplan, 2000, p. 502; Kempton et al., 1995, pp. 124, 136-137, 219). For instance, the "home-power movement" appeals to middle-class Americans who gain satisfaction from skill cultivation by crafting technological innovations that reduce the distance between production and consumption and result in diminished fossil-fuel combustion and a smaller ecological footprint (Tatum, 2002).

Perhaps the most impressive linkage that addresses consumptive behavior in the USA is the mainstream voluntary-simplicity movement. At the core of voluntary simplicity is "improved consumption efficiency" - that is, increasing human satisfaction by decreasing the type of material consumption that brings net harms to others (Manno, 2002, p. 67; Princen, 2002, p. 34). The link to intrinsic satisfaction is not through sacrifice, but through the personal challenges, excitement, and the diverse co-benefits that accrue from frugality and simple living - including reduced job-related stress, increased control over one's time, outdoor exercise, rewarding family/social relations, additional artistic, intellectual, and political contributions, and greater balance and meaning in life (Maniates, 2002b, pp. 199, 201, 212, 216-217, 221, 223; Schor, 1998, pp. 113-114, 146, 152; Harwood Group, 1995, pp. 14-18; Macnaghten and Jacobs, 1997, p. 13; De Young, 1993, p. 501; De Young, 2000, pp. 515-523; Kaplan, 2000, pp. 495, 500; Winter, 1996, p. 107; Werner and Makela, 1998, p. 382; Ophuls and Boyan, 1992, pp. 290, 282; Zavestoski, 2001, pp. 173, 185). Also relevant in terms of consumption-efficiency behavior and modeling in the United States are statistical indications that first-generation Chinese Americans and persons who speak Chinese at home use far less energy per capita across all income groups and produce far less $\mathrm{CO}_{2}$ per capita in comparison with the mainstream population (Lutzenhiser, 1997, pp. 86-87).

2.4.1.3. Transportation Choices. Transportation choices merit special attention in connection with bundling health, consumption, and emissions. Throughout much of the world, the private automobile tends to be valued as "both a personal and a national symbol of success and status" (Zhou and Sperling, 2001, p. 12). Although 
the transportation sector currently only is responsible for about 10 per cent of China's total energy-related carbon emissions, the sale of automobiles is growing dramatically (Lun, 2003, p. 28; Chandler et al., 2002, p. 14; also see Manning, 2000, p. 105). Pew Center on Global Climate Change analysts predict that transportation greenhouse-gas emissions in Shanghai will grow between 4 (low scenario) and 7 (high scenario) times the 2000 level by 2020 - in large part due to "rapid increases in long-suppressed car ownership" (see Zhou and Sperling, 2001, pp. 24-30; Sperling and Salon, 2002, pp. 31-32). Given current trends, China's transportation fuel consumption will reach current U.S. levels by 2030 (He, 2003, p. 13).

Although many Chinese value the automobile as a status symbol and are not likely in the immediate future to avoid vehicle purchases out of GHG concerns (see Zhou and Sperling, 2001, pp. 12, 24), transportation-emission reductions are amenable to persuasion in China via the "linkage with local environmental concerns" principle. Appeals to people's health concerns are particularly promising and largely untapped avenues for reducing vehicle emissions by transforming air pollution into a compelling personal motivation for diminished use (Stockholm Environment Institute, 2002, p. 48). Motor-vehicle emissions of hydrocarbons, carbon monoxide, and oxides of nitrogen simultaneously are major sources of global climate change and adverse local health effects from ground-level pollution (Walsh, 1989 , p. 264). As a result of the expansion of automotive sales, vehicle emissions already have replaced coal soot as the principal source of air pollution in a number of China's cities (Baldinger and Turner, 2002, p. 13). According to one report, "CO and $\mathrm{NO}_{x}$ emissions from the transportation sector now together account for over 60 per cent of total urban air pollution" (Qian et al., 2003, p. 35; also see Zhao and Gallagher, 2003, p. 20; He, 2003, p. 13). These gases, combined with lead and particulate emissions, are among the principal risk factors associated with "diseases that are the leading causes of death in China" - such as lung cancer, bronchitis, and pulmonary heart disease (Stockholm Environment Institute, 2002, p. 32; Sperling and Salon, 2002, p. iv; also see Kunzli et al., 2000, p. 795; Patterson, 2000, p. 259).

Residents of poor countries are especially prone to "see their health as being negatively affected by environmental problems" (Dunlap et al., 1993, pp. 12, 14) and urban dwellers in many Chinese cities are exposed to the most healthdamaging levels of air pollution in the world (Stockholm Environment Institute, 2002, pp. 26, 31). The race to develop fuel-cell automobiles and buses for Beijing in time for the 2008 Olympics provides a special opening for Chinese transmigrants to support state-of-the-art vehicle-manufacturing and hydrogen-storage and refueling systems that, in the long term, promise zero pollution (see Sperling and Salon, 2002, pp. 17, 19; Qian et al., 2003, pp. 34, 37-40) and to emphasize the attractiveness of non-motorized transportation (see Sperling and Salon, 2002, pp. 23-24, $34)$. Jimin Zhao and Kelly Gallagher (2003, p. 27) point out that consumer education has unique potential to generate thriving demand for nonGHG-emitting vehicles because most Chinese have not habitually owned and operated conventional 
automobiles. In such future-oriented, transportation emissions-influencing roles, transmigrants are particularly likely to comprehend the indigenous challenges that need to be surmounted, to recognize local possibilities, to be cognizant of North American "mistakes and detours" (Sperling and Salon, 2002, p. 33), and to appreciate adaptive possibilities such as the introduction of a "bicycle curriculum" at the primary-school level (Devlin, 2003, p. B4).

Among the U.S. population, the most fossil-fuel-energy-intensive activities involve transportation (Schipper et al., 1989, p. 317). Stephen Potter (2001, pp. 139141) shows that improvements in vehicle technology alone will not reduce $\mathrm{CO}_{2}$ emissions from automotive transportation to sustainable levels. Curtailing automobile emissions primarily requires addressing "the amount and length of journeys" (Potter, 2001, pp. 141-142; Kempton et al., 1995, p. 34). In the Bord et al. (2001, p. 211) survey of U.S. public dispositions toward five "voluntary-action" options, however, the smallest percentage of respondents indicated that they were likely to "drive less."

According to William Dietz, Director of the Division of Nutrition and Physical Activity at the Centers for Disease Control and Prevention, "a quarter of all trips taken by Americans are under a mile, but 75 percent of those trips are done by car" (cited in Brody, 2000, p. El). Moreover, bicycle ridership is declining in the United States (down from 56 million in 1995 to 43.5 million in 1998) and, while nearly 10 million school-age children are obese (Stengle, 2004), less than 1 per cent of those aged 7 to 15 ride bicycles to school (Kilborne, 1999, p. Al). In contrast, roughly one out of every two Shanghai residents uses a bicycle. In 1995, the city's inhabitants made 60 per cent of their (mostly short) trips by biking or walking (Zhou and Sperling, 2001, pp. 5-6). At the turn of the century, foot-power friendly China boasted the world's lowest rates of obesity among men and women aged 35 to 64 (McQueen et al., 2001, p. 320). ${ }^{12}$

Although "bicycle-friendly communities" have sprung up in places such as Corvallis, Oregon, Palo Alto, California, and Missoula, Montana (Devlin, 2003, pp. B1, B4), there is much of climatic, health, and resource-conservation value that U.S. drivers who value individual mobility could learn from China's time-saving city-wide bike lanes (see Lowe, 1989, p. 21; Sperling and Salon, 2002, pp. 7, 11; Hook, 1996, p. 4); convenient and inexpensively guarded bike-parking areas; bicycle load carrying and delivery; and extensive system of sidewalk bicycle-repair stations. Commuter subsidies for cyclists also merit consideration as an emissionsreduction strategy. Chinese transmigrants who are experienced with the "vehicle of the future" (the bicycle) can make an important contribution to emission reductions and chronic-illness prevention by encouraging U.S. American friends and neighbors to move their bikes from garages where they are collecting dust (Lowe, 1989, pp. 7-18) out into commuting and shopping lanes. They also can employ linked U.S./China climatic-stabilization narratives to promote the provision of cyclistand pedestrian-friendly lanes and routes and the curtailment of short car trips particularly during peak traffic hours (see Schipper et al., 1989, pp. 316-317). 


\subsubsection{Principle Bundling: Applying Climatic-stabilization Narratives Transnationally and Locally}

In a time of political impasse when many citizens perceive that governmental institutions are not committed to solving environmental problems, issue bundling might not be sufficient to overcome entrenched obstacles to sustainable-consumption practice. In their U.K. focus-group study, Macnaghten and Jacobs (1997, pp. 20-21) found that "action is regarded as efficacious only when people trust the institutions promoting the action." In today's North-South context, trust building requires that nonstate actors devote attention to principle bundling as well as issue bundling. In the specific context of mutual responsibility for global warming, issue bundling must be joined with principle bundling if individuals in China and the United States are to perceive that their actions will be reciprocated and, thereby, make a difference in an interdependent world.

To change consumption behavior among individuals and households, the "bulk of climate-change politics will have to devolve to the local level ..." (O'Riordan and Jager, 1996, p. 358; Uzzell, 2000, p. 317) where trusted relationships exist (Macnaghten and Jacobs, 1997, p. 21). In order for transnational and national activists to participate effectively in devolved value-(re)framing and behavior-change efforts that address $\mathrm{CO}_{2}$ emissions, their actions, investments, and recommendations need to be guided by linked global/local narratives built upon durable legitimating, motivating, and implementing principles. As Thomas Princen (2003, p. 44) explains, "a principle is socially useful because it routinely generates particular questions ... as a continual means of raising and espousing critical values."

The foundation piece for climatic-stabilization narratives of transPacific action is the principle of common but differentiated responsibility that has been vigorously advanced by the PRC Government and is now widely accepted (Barrett, 1999, pp. 210-211; Chayes and Kim, 1998, pp. 509-510; Paterson, 1996, pp. 61, 66; Cooper, 1992, p. 305; Ross, 1998, p. 819) - even by the U.S. Government. ${ }^{13}$ The consequences of climatic-system change cannot be "outsourced." However, perceived inequities in response undermine collaborative conservation efforts (Bell et al., 2001, p. 479). Drawing on historical, current, and projected future per-capita emissions, ${ }^{14}$ a "common but differentiated responsibility" principle of nonstate relations would affirm mutual action and cooperation among transnational and national activists in China and the United States for the sake of shared environmental and health interests (see Zhang, 2000, p. 749) and to minimize public resistance in both societies (Darier and Schule, 1999, p. 326; Harwood Group, 1995, p. 2). For the climatic-stabilization narrative, common but differentiated responsibility is usefully joined to the implementing principle of additionality; that is, contributions to climatic-stabilization efforts should be above and beyond any prior commitments, legal obligations, technology and capacity transfers, or emission reductions/removals that otherwise would have occurred (see Danish and Rotter, 2001, p. 170; Chayes and Kim, 1998, p. 511). The premises underpinning these principles are that both rich and poor will take mutually beneficial actions, the 
magnitude and timing sequence of which are commensurate with relative levels of economic development and respective capacities - with the rich (persons in the United States) undertaking the bolder initiatives and providing the less advantaged (persons in China) with a larger share of the requisite funding and technology (also see Ashton and Wang, 2003, pp. 70-71).

The possibilities inherent in the common-but-differentiated transnational distribution of costs and benefits are easily grasped and explored by dual-identity Chinese overseas. By translating these legitimating principles in ways that "enhance their compatibility with national conditions and cultural orientations" and blending them with traditional mandates and concerns (Steinberg, 2003, pp. 25-26, 184-185) on both sides of the Pacific, proximate and credible Chinese transnational activists are able to help foster incentive-compatible cooperation by highlighting net benefits to all participants, reinforcing emissions-reducing behavior through personal contributions and positive feedback, and confirming that communities across the PRC and the USA are undertaking sustained commitments.

At the same time that the principles of common-but-differentiated responsibility and additionality legitimize Chinese American participation in transferring resources, technology, and expertise from U.S. sources in support of expanded efforts to reduce $\mathrm{CO}_{2}$ (and other GHG) emissions within China, they do not exempt Mainland Chinese from climate-change mitigation. Gielen and Chen (2001, p. 268), for instance, recognize that "given the phenomenal growth of the Chinese economy, and emission levels in Shanghai that are approaching levels in industrialised countries, it seems reasonable that some of the financial burdens are borne by the Chinese side." Trusted Chinese transnationals are uniquely suited for spreading the shared, but differentiated, message. In contrast, "when Northern scientists, environmentalists, or policy makers begin to talk about restraining consumption or restricting emissions in developing countries, they are liable to be accused of a neocolonial agenda" (Wilk, 1998, p. 318).

While promising as a means of securing U.S.-China nonstate cooperation, the "common but differentiated responsibility" and additionality principles are likely to lack sufficient motivational force of their own. In order to gain motivational power, they need to incorporate two other notions that touch directly upon personal interests that are widely shared among members of civil society. The first motivating principle is integration with local environmental concerns. In general, lay publics (and political actors) will be more receptive to measures that will mitigate noticeable emissions responsible for pollution and other negative health/economic consequences in one's locality (see, for instance, Frank, 2000; Chandler et al., 2002, p. 52; Bickerstaff and Walker, 2001, p. 143; Chiu et al., 2003).

The second inspiring motive is concern for future generations. Concern for the healthy future and welfare of descendants and children generally offers a powerful common motivator among publics in both China and the United States (see Weller and Bol, 1998, pp. 493-494; Kempton, 1993, p. 237; Kempton et al., 1995, p. 95; Harwood Group, 1995, pp. 7, 13; Dunlap et al., 1993, pp. 12, 15). This motivating 
notion is enhanced by inclusion of two implementing principles advanced by Princen (2003, p. 46): restraint - "using [and reproducing] less than what is physically or technically or legally or financially possible" - and precaution - corrective action is called for in the face of critical and potentially irreversible threats to fragile life-support systems "even if the science is not conclusive" and "there is not enough evidence to determine for sure" whether the predicted harm from human activities will occur (Jasanoff, 2001, pp. 331-332; also see Princen, 2002, pp. 3940; O’Riordan and Jordan, 1996, p. 95; Spray and McGlothlin, 2002, p. 155). Including intergenerational legitimating, motivating, and implementing principles is especially important in the case of global climatic change since (1) the most damaging impacts of anthropogenic warming are time-lagged (Adger et al., 2001, p. 581; Uzzell, 2000, p. 315; McDonald, 2005, p. 220); (2) with "business as usual," the options for addressing climate alteration diminish dramatically for future generations (Claussen and McNeilly, 1998, p. 7; Nielsen and McElroy, 1998, p. 4; Roberts, 2004, pp. 126-127; Redclift, 1995, p. 11); (3) population control is essential for sustainable consumption and GHG-emissions reductions (Claussen and McNeilly, 1998, pp. 2, 20); and (4) efforts to control emissions will need to be sustained over time.

In sum, adapting the comprehensive "common but differentiated responsibility for present and future generations" principle to the nonstate context considered in this article would involve Chinese transnationals in efforts to change the value and practice base of human-induced $\mathrm{CO}_{2}$ emissions through linked and bundled climatic-stabilization narratives based on direct personal experience that are legitimate and persuasive on both sides of the Pacific. People are ready to be engaged when consumption issues are framed in terms of bundled issues and principles (see Harwood Group, 1995, p. 23). Given their access to independent and flexible networks built on mutual trust, the involvement of competent Chinese transnationals promises to be particularly effective at building capacity for behavioral change at individual, family, organizational, and community levels where they can partner with increasingly influential allies, such as "downshifters" or "simplifiers" in the United States (Blake, 1999, p. 261; Maniates, 2002b, pp. 227, 232; Miller, 1995) and public-health advocates in China.

\section{Conclusion: Progress and Prospects at the Nonstate Level in the USA and PRC}

In an age of political paralysis, synergetic alliances of transnational and national activists operating along and across porous nation-state boundaries through civilsociety networks and independent, low-profile, grassroots, and long-term interpersonal and interorganizational involvements constitute a key social dynamic in efforts to constrain consumptive behavior and to control GHG emissions. In the face of the entrenched obstacles to binding GHG reductions and the deep-rooted political resistance to fundamental modifications in expansionist economic policies 
that prevail in Beijing and Washington, D.C., climatic-stabilization advocates must rely on efforts to reorient population values and emissions-related decision making that are not dependent on central government initiatives in the policy-making arena (also see Princen et al., 2002, p. 4). Admittedly, the curtailment of consumptive behaviors is multiply determined and more problematic in the absence of national government action. At present, however, globally linked nongovernmental actors and transnational networks offer "the most exciting arena for innovation in climate change politics" (O'Riordan and Jager, 1996, p. 358; also see Steinberg, 2001, pp. 205-206; Conca, 2002, p. 152; Stoll-Kleemann et al., 2001, p. 116; Betsill and Bulkeley, 2004, p. 489). ${ }^{15}$

Prominent among the potentially decisive transnational activists are Chinese overseas - scientists, academics, engineers, investors, charitable donors, and cultural leaders who possess interest and competence in mitigating the detrimental ecological, economic, and health effects of projected anthropogenic climatic changes on China, the United States, and the global commons. While they constitute a small percentage of this country's of the total U.S. population and tend to work below the media's radar screen, a disproportionate number of highly educated Chinese Americans are professionally active in the powerful scientific, environmental, highereducation, cultural, philanthropic, and business organizations that operate on both sides of, and across, the Pacific. In the realm of climatic stabilization, the lengthy list of influential and dedicated Chinese Americans and returning Chinese transnationals likely would include the World Resources Institute's Wendy Tao, Project Coordinator for an effort to improve Shanghai's transport system while reducing air pollution and GHG emissions (staff.wri.org/staff_biosketch.cfm?StaffID=354; China Environment Series 6, 2003, 178-179) and Wei-shiuen Ng, a specialist on the economic impact of sea-level rise; Gan Lin, Director of the World Wildlife Fund (China)'s "human dimensions of climate change" initiative and his large staff of overseas and returning Chinese (Harkness, 2004; China Environment Series 6, 2003, 239); Jimin Zhao, Harvard University researcher working in collaboration with partners in China on alternative transportation policies (Zhao and Gallagher, 2003); Jiang Lin, scientist at the Lawrence Berkeley National Laboratory (see Yi, 2002, p. 1); Angela Chen of Iowa's Department of Natural Resources, leader of a 2002 China Environment Forum-sponsored workshop session in three Mainland cities on the use of municipal bonds to raise capital for energy-efficiency improvements (China Environment Series 6, 2003, 141); Sophie Chou of the Pew Center on Global Climate Change (Aldy et al., 2003, p. iv); ZhongXiang Zhang at the EastWest Center (Aldy et al., 2003, p. iv); Xueman Wang of the Centre for International Sustainable Development Law (Ashton and Wang, 2003); Li Ping of DSC Communications Corporation (Dong et al., 1998, p. 119); University of Colorado Assistant Professor of Geography, Emily T. Yeh (2004); Wei Min Hao, a U.S. Forest Service senior scientist who leads a group that assesses the impact of forest and savanna fires on global air pollution and global climatic change; and Harvard University's influential scholar Tu Wei-ming. 
On a less-visible level, many Chinese transmigrants, who now find the prevailing U.S. lifestyle less satisfying than they did upon arrival, are embracing more fulfilling traditional Chinese values and ways of life and exploring the postmaterialist insights they gained from personal experience in the United States with their Mainland relatives, friends, and colleagues (Xiao-huang Yin, personal communication, June 2004; also see Zavestoski, 2001, pp. 175-176, 186; Stern, 2000, p. 420; Murphy and Cohen, 2001, p. 228). The transnational lives and direct production/consumption/waste observations of some Chinese overseas provide the experiential basis for critical reflection, for making cultural- and spatial-distancereduction linkages to personal risks (Conca, 2002, p. 143; Uzzell, 2000, p. 316; Clapp, 2002, p. 155), and for framing and spreading linked local/global narratives (Betsill and Bulkeley, 2004, p. 489) regarding culprits and contributors, motivating and implementing principles, and reciprocal emissions-mitigating actions in ways that fit values on both sides of the Pacific.

Chinese transnationals, especially Chinese Americans, have a special role to play in the PRC and the USA as issue-(re-)framers, conversation-initiators, and behavior-change inspirers by offering powerful testimony and reinforcing feedback regarding the co-benefits involved in sustainable lifestyles - reduced stress and improved health, close and dependable interpersonal relationships with family and friends, contributions to the global commons. Armed with a persuasive message and political acumen, Chinese transnationals are especially effective role models because they are highly regarded in their place of origin and because observers perceive that they will receive the same benefits as those secured by benchmark individuals who resemble themselves (Bell et al., 2001, p. 488; Maniates, 2002b, p. 204; Gladwell, 2000, pp. 258-259). In addition, they are uniquely qualified to monitor and report on the reciprocal personal behavior changes being undertaken, or not being undertaken, in today's two most climatic-impacting societies.

Although nonstate actors are not likely by themselves to arrest climatic-system change (see Bell et al., 2001, p. 496; Maniates, 2002b, pp. 216, 219, 231; Murphy and Cohen, 2001, p. 235) and further research is required regarding the ways that specific groups of transnational actors induce durable attitudinal and behavior modification (Cohen, 2001, pp. 28, 35; Barr, 2002, p. 170), the growing involvement of Chinese and nonChinese activists in emission-mitigation projects, value change, and sustainable-consumption practices provides a promising beacon for future possibilities. Climate science should not ignore or downplay such "micro" contributions because of the difficulties involved in accounting for social behavior (Rosenau, 2003, p. 26).

Confidence that one is able to bring about change provides a major source of motivation for transnational interventions (see DeYoung, 2000, pp. 521522; Kaplan, 2000, p. 498). Transnationally competent immigrant and U.S.born Chinese American professionals increasingly are inclined to perceive their bicultural heritage as an asset in today's world and to become involved in 
transnational and national (U.S. and P.R.C.) interactions (see, for instance, Yin, 1999, pp. 332-336). Many Chinese transmigrants already have demonstrated considerable entrepreneurial skill at refining and synthesizing unfamiliar ideas and approaches in innovative ways that enhance their local relevance, popularity, and profitability. Contributing their special place-based insights and skills in community participation and resource frugality (DeYoung, 2000, p. 522) to value change, consumption-efficient behavior, and the diffusion of GHG-emissionsreduction ideas and technologies among the world's two most responsible populations presents a novel and personally fulfilling opportunity for Chinese overseas that merits encouragement.

The extent to which Chinese transnational activists will become a factor in emissions-reduction efforts in future years depends upon the outcome of interconnected developments. Far-sighted and transnationally competent community members who are personally committed to participate in addressing the threats posed by global warming to the PRC, the USA, and the global commons (Stern et al. 1993, p. 324) must be able to mobilize the requisite skills, information, and resources around legitimating and motivating narratives that encompass reduced health risks, the well-being of future generations, and common-but-differentiated responsibility for GHG emissions. To succeed, moreover, they must develop innovative and enduring confidence-building alliances with national activists and pursue locally appropriate strategies and projects that further sustainable-consumption practices. Although the outcomes of linked interpersonal interactions and transnational processes are difficult to measure with precision (see Nakicenovic et al., 2000, p. 121), it is reasonable to suggest that, with support from mainstream nongovernmental allies in both countries who are interested in personal/family/public health and less stressful/more meaningful lives, Chinese transnationals will serve as influential role models and persuasive initiators of emissions-reducing projects and sustainableconsumption behavior among the most populous and the most gluttonous societies on Earth.

Chinese transnationals are a key overlooked and underestimated piece in the current emissions-reduction puzzle. They occupy a special position at the intersection of values, behavioral change, and nongovernmental institutions directly and indirectly involved in climatic-change mitigation. Given their dual U.S./P.R.C. leverage in a complex situation where national government commitments and actions continue to be unlikely, other actors concerned with building a sustainableconsumption movement (Princen et al., 2002, p. 20) and with climatic stabilization are likely to benefit from devoting increased attention and transferring additional responsibilities to this group. Centering the Chinese transnational piece on the multidimensional emissions-reduction board introduces fitting prospects that would link the two principal emitters, national and transnational activists, individuals and nongovernmental organizations, South and North, legitimating, motivating, and implementing narratives, and general values with specific problem appreciation and consumptive-behavior change. 


\section{Acknowledgement}

The author acknowledges with gratitude the helpful comments provided by Paul $\mathrm{N}$. Edwards and two anonymous reviewers on earlier versions of this article.

\section{Notes}

'The Bush Administration finally acknowledged that GHG emissions are the only likely explanation for recent decades of global warming in an August 2004 report to Congress. In October 2004, however, NASA climate expert James E. Hansen publicly claimed that a senior Bush Administration official had told him not to "talk about dangerous anthropogenic interference" (Revkin, 2004, p. A20; also see Revkin, 2005).

${ }^{2}$ As a result of continued population growth combined with expanded production (much of which is destined for the U.S. market) and increased per-capita consumption, the People's Republic of China (PRC) is expected to overtake the USA as the number one gross GHG emitter within several decades (Roberts, 2004, pp. 122, 145; Kroeze et al., 2004, p. 55; U.S.E.I.A., 2004, pp. 1-2; Banister, 1998).

${ }^{3}$ An important recent exception is Betsill and Bulkeley (2004).

${ }^{4} \mathrm{As}$ used in this article, activists are persons who are intentionally involved in some activity related to climatic stabilization. Thus, the term is not restricted to persons who participate in demonstrations or similar types of protest activity.

${ }^{5}$ See Verba (2003, pp. 668-669) on the tendency for educated citizens to be committed to civic concerns and to be more engaged politically in comparison with persons who do not possess a college education.

${ }^{6}$ Of course, one also finds transnationally competent persons who are not of Chinese descent working in the Mainland.

${ }^{7}$ By May 2005, the mayors of 132 U.S. cities had pledged to reduce GHG emissions to Kyoto Protocol target levels by 2012 (Sanders, 2005, p. A8).

8 On the expressed willingness of Chinese citizens to pay more for renewable and nonpolluting sources of energy, see Gan, (2001, pp. 9, 13-14).

${ }^{9}$ Consumption trajectories cannot be understood by viewing individual consumers as autonomous actors. Consumption practices are profoundly shaped by contextual power relationships and social connections, including network and group influences (Murphy and Cohen, 2001, p. 227; Princen et al., 2002, pp. 14-15; Maniates, 2002a, pp. 60, 65; Eden, 1993, pp. 1745, 1749; Stern, 2000, pp. 417419).

${ }^{10}$ Princen et al. (2002, p. 3) define commoditization as "the substitution of marketable goods and services for personal relationships, self-provisioning, culture, artistic expression, and other sources of human well-being."

${ }^{11}$ On the role of the media in promoting environmental awareness in China in recent years, see Bo (1998); Stockholm Environment Institute (2002, pp. 48, 86-87).

${ }^{12}$ However, the number of obese people in China doubled from 1992 to 2002 (New York Times, 13 October 2004, p. A6).

${ }^{13}$ In April 2001, for instance, the Bush Administration agreed to a treaty controlling harmful organic chemicals that "calls for rich and poor countries to move in concert, but...requires industrialized countries to provide the money and technology to help the cleanup in the developing world" (Revkin, 2001, p. A7).

${ }^{14}$ Current GHG emissions per capita in the China Mainland are estimated to be one-eighth of those in the USA, but are expected to increase to one-fifth by 2020 in a business-as-usual scenario (Bradsher, 2003, p. Al; Kroeze et al., 2004, p. 70). 
${ }^{15}$ On the main nongovernmental organizations active in networking globally for health promotion, see www.phmovement.org/pha2000/index.html (updated 23 June 2005).

\section{References}

Adger, W. N., et al.: 2001, 'Asia: Contribution of working group II to the third assessment report of the intergovernmental panel on climate change', in James J. McCarthy et al. (eds.), Climate Change 2001: Impacts, Adaptation, and Vulnerability, Cambridge: Cambridge University Press, pp. 533-590.

Ajzen, I.: 1991, 'The theory of planned behavior', Organizational Behavior and Human Decision Processes 50, 179-211.

Ajzen, I. and Fishbein, M.: 1980, Understanding Attitudes and Predicting Social Behavior. Englewood Cliffs: Prentice-Hall.

Aldy, J. E., et al.: 2003, Beyond Kyoto: Advancing the International Effort against Climate Change. Arlington: Pew Center on Global Climate Change.

An, F.: 2003, 'Personal cars and China', Sinosphere Journal 6(1), 6-13.

Andrews, E. L.: 2001, 'Frustrated Europeans set to battle U.S. on climate', New York Times 16 July, p. A3.

Andrews, E. L.: 2005, 'Snow urges consumerism on China trip', New York Times 14 October, p. C1.

Ash, R. F. and Edmonds, R. L.: 1998, 'China's land resources, environment and agricultural production', China Quarterly 156, 836-879.

Ashton, J. and Wang, X.: 2003, 'Equity and climate in principle and practice', in Joseph E. Aldy et al. (eds.), Beyond Kyoto: Advancing the International Effort Against Climate Change, Arlington: Pew Center on Global Climate Change, pp. 61-83.

Baldassare, M. and Katz, C.: 1992, 'The personal threat of environmental problems as predictor of environmental practices', Environment and Behavior 24(5), 602-616.

Baldinger, P. and Turner, J. L.: 2002, Crouching Suspicions, Hidden Potential: United States Environmental and Energy Cooperation with China. Washington, D.C.: Wilson Center.

Bamberg, S.: 2003, 'How does environmental concern influence specific environmentally related behaviors? A new answer to an old question', Journal of Environmental Psychology 23(1), 2132.

Banister, J.: 1998, 'Population, public health, and the environment in China', China Quarterly 156, 986-1015.

Barr, S.: 2002, Household Waste in Social Perspective: Values, Attitudes, Situation and Behavior. Aldershot: Ashgate.

Barr, S., Ford, Nicholas, J., and Gilg, A. W.: 2003, 'Attitudes towards recycling household waste in Exeter, Devon: Quantitative and qualitative approaches', Local Environment 8(4), 407-421.

Barrett, S.: 1999, 'Montreal versus Kyoto: International cooperation and the global environment', in Inge Kaul, Isabelle Grunberg, and Marc A. Stern (eds.), Global Public Goods: International Cooperation in the 21st Century, Oxford: Oxford University Press, pp. 192-219.

Bell, P. A., et al.: 2001, Environmental Psychology, 5th edition. Forth Worth: Harcourt.

Betsill, M. M. and Bulkeley, H.: 2004, 'Transnational networks and global environmental governance: The cities for climate protection program', International Studies Quarterly 48, 471-493.

Bickerstaff, K. and Walker, G.: 2001, 'Public understandings of air pollution: The 'localisation' of environmental risk', Global Environmental Change 11, 133-145.

Birdsall, N. and Lawrence, R. Z.: 1999, 'Deep integration and trade agreements: Good for developing countries?', in Inge Kaul, Isabelle Grunberg, and Marc A. Stern (eds.), Global Public Goods: International Cooperation in the 21 st Century, Oxford: Oxford University Press, pp. 128-151. 
Blake, J.: 1999, 'Overcoming the 'Value-Action Gap' in environmental policy: Tensions between national policy and local expertise', Local Environment 4(3), 257-278.

Bo, W.: 1998, 'Greening the Chinese media', China Environment Series 2 Environmental Change and Security Project, Woodrow Wilson International Center for Scholars. htttp//ecsp.si.edu/ecsplib.nsf

Bord, R. J., Fisher, A. and O'Connor, R. E.: 1998, 'Public perceptions of global warming: United States and international perspectives', Climate Research 11, 75-84.

Bord, R. J., O'Connor, R. E., and Fisher, Ann.: 2000, 'In what sense does the public need to understand global climate change?', Public Understanding of Science 9, 205-218.

Boudri, J. C., et al.: 2002, 'The potential contribution of renewable energy in air pollution abatement in China and India', Energy Policy 30(5), 409-424.

Bradsher, K.: 2003, 'China's boom adds to global warming problem', New York Times 22 October, pp. A1, A8.

Brechin, S. R.: 2003, 'Comparative public opinion and knowledge on global climatic change and the Kyoto Protocol: The U.S. versus the world', International Journal of Sociology and Social Policy 23(10), 106-127.

Brody, J. E.: 2000, 'Planning healthier suburbs, where cars sit idle and people get moving', New York Times, 17 October, p. E1.

Bush, G. W.: 2001, 'Global climate change: Making commitments we can keep and keeping commitments we can make', Vital Speeches of the Day 68(18), 546-548.

Castleman, B.: 2004, 'The international struggle over asbestos', Presidential Lecture, The University of Montana, 5 April.

Chan, K.: 1998, 'Mass communication and pro-environment behavior: Waste recycling in Hong Kong', Journal of Environmental Management 52, 317-325.

Chandler, W., et al.: 2002, Climate Change Mitigation in Developing Countries. Arlington: Pew Center on Global Climate Change.

Chase, J. and Panagopoulos, I. S.: 1995, 'Environmental values and social psychology: A European common market or commons' dilemma?', in Yvonne Guerrier, Nicholas Alexander, Jonathan Chase, and Martin O'Brien (eds.), Values and the Environment: A Social Science Perspective, Chichester: John Wiley \& Sons, pp. 67-79.

Chayes, A. and Kim, C.: 1998, 'China and the United Nations Framework Convention on Climate Change', in Michael B. McElroy, Chris P. Nielsen, and Peter Lydon (eds.), Energizing China: Reconciling Environmental Protection and Economic Growth, Cambridge: Harvard University Press, pp. 503-540.

Chen, S. and Uitto, J. I.: 2003, 'Governing marine and coastal environment in China: Building local government capacity through international cooperation', China Environment Series 6, 67-80.

Chiu, K., Green, C., and Sibold, K.: 2003, 'Air quality and greenhouse gas co-benefits of integrated strategies in China', Sinosphere Journal 6, 1, 40-47.

Cifuentes, L., Borja-Aburto, V. H., Gouveia, N., Thurston, G., and Davis, D. L.: 2001, 'Hidden health benefits of greenhouse gas mitigation', Science 293, 1257-1259.

Clapp, J.: 2002, 'The distancing of waste: Overconsumption in a global economy', in Thomas Princen, Michael Manatiates, and Ken Conca (eds.), Confronting Consumption, Cambridge: MIT Press, pp. 155-176.

Claussen, E. and McNeilly, L.: 1998, Equity and Global Climate Change: The Complex Elements of Global Fairness. Arlington: Pew Center on Global Climate Change.

Cohen, M. J.: 2001, 'The emergent environmental policy discourse on sustainable consumption', in Maurie J. Cohen and Joseph M. Murphy (eds.), Exploring Sustainable Consumption: Environmental Policy and the Social Sciences, vol. 1, Amsterdam: Pergamon, pp. 21-37.

Committee on Scholarly Communication with the People's Republic of China. 1992. China and Global Change: Opportunities for Collaboration. Washington, D.C.: National Academy Press. 
Conca, K.: 2002, 'Consumption and environment in a global economy', in Thomas Princen, Michael Manatiates and Ken Conca (eds.), Confronting Consumption, Cambridge: MIT Press, pp. 133153.

Cooper, R. N.: 1992, 'United States policy towards the global environment', in Andrew Hurrell and Benedict Kingsbury (eds.), The International Politics of the Environment: Actors, Interests, and Institutions, Oxford: Clarendon, pp. 290-312.

Danish, K. W. and Rotter, J. C.: 2001, 'Drafting contracts for greenhouse gas offset projects in developing countries', Natural Resources and Environment 15(3), 168-171, 206207.

Darier, E. and Schule, R.: 1999, 'Think globally, act locally'? Climate change and public participation in Manchester and Frankfurt', Local Environment 4(3), 317-329.

Davis, D. L., et al.: 1997, 'Short-term improvements in public health from global-climate policies on fossil-fuel combustion: An interim report', Lancet, 350, 1341-1349.

Devlin, V.: 2003, 'National organization names Missoula a bicycle-friendly community', Missoulian, 20 May, p. B1.

De Young, R.: 1990/1991, 'Some psychological aspects of living lightly: Desired lifestyle patterns and conservation behavior', Journal of Environmental Systems 20(3), 215-227.

De Young, R.: 1993, 'Changing behavior and making it stick: The conceptualization and management of conservation behavior', Environment and Behavior 25(4), 485-505.

De Young, R.: 2000, 'Expanding and evaluating motives for environmentally responsible behavior', Journal of Social Issues 56(3), 509-526.

Dong, F., Lew, D., Ping, L., Kammen, D. M., and Wilson, R.: 1998, 'Strategic options for reducing $\mathrm{CO}_{2}$ in China: Improving energy efficiency and using alternatives to fossil fuels', in Michael B. McElory, Chris P. Nielsen, and Peter Lydon (eds.), Energizing China: Reconciling Environmental Protection and Economic Growth, Cambridge: Harvard University Press, pp. 119165.

Dunlap, R. E., Gallop, G. H., and Gallop, A. M.: 1993, 'Of global concern: Results of the health of the planet survey', Environment 35(9), 6-22.

Durning, A. T.: 1992, How Much Is Enough? The Consumer Society and the Future of the Earth. New York: W. W. Norton.

Economy, E. C.: 2001, 'The impact of international regimes on Chinese foreign policy-making: Broadening perspectives and policies... but only to a point', in David M. Lampton (ed.), The Making of Chinese Foreign and Security Policy in the Era of Reform, 1978-2000, Stanford: Stanford University Press, pp. 230-253.

Economy, E. C.: 2004, The River Runs Black: The Environmental Challenge to China's Future. Ithaca: Cornell University Press.

Eden, S. E.: 1993, 'Individual environmental responsibility and its role in public environmentalism', Environment and Planning A 25, 1743-1758.

Eden, S. E.: 1996, 'Public participation in environmental policy: Considering scientific, counterscientific and non-scientific contributions', Public Understanding of Science 5, 183-204.

Fazio, R. H. and Zanna, M. P.: 1981, 'Direct experience and attitude-behavior consistency', Advances in Experimental Social Psychology 14, 161-202.

Ferris, R. J. and Zhang, H.: 2002, 'The challenges of reforming an environmental legal culture: Assessing the status quo and looking at post-WTO admission challenges for the People's Republic of China', Georgetown International Environmental Law Review 14(3), 429-460.

Frank, A.: 2000, 'The environment in U.S.-China relations: Themes and ideas from working group discussions', China Environment Series 1, Environmental Change and Security Project, Woodrow Wilson International Center for Scholars. http//ecsp.si.edu/ecsplib.nsf.

Gan, L.: 2001, 'Promoting green electricity development from industrial to developing countries: What needs to be done', Sinosphere Journal 4(1), (Winter), 9-15. 
Gielen, D. and Chen, C.: 2001, 'The $\mathrm{CO}_{2}$ emission reduction benefits of Chinese energy policies and environmental policies: A case study for Shanghai, period 1995-2020', Ecological Economics 39(2), 257-270.

Gladwell, M.: 2000, The Tipping Point: How Little Things Can Make a Big Difference. Boston: Little, Brown and Company.

Hakim, D.: 2004, 'California backs plan for big cut in car emissions', New York Times, 25 September, A1, B3.

Hall, C. A. S.: 2004, 'The myth of sustainable development: Personal reflections on energy, its relation to neoclassical economics, and Stanley Jevons', Journal of Energy Resources Technology 126, $85-89$.

Harkness, J.: 2004, 'Globalization and the Chinese environment', Keynote Address Presented at the 20th Annual Mansfield Conference, "The Complex Face of Globalization in China," University of Montana, Missoula, 18 April, April.

Harwood Group: 1995, Yearning for Balance: Views of Americans on Consumption, Materialism, and the Environment. Takoma Park: Merck Family Fund.

Hawthorne, M. and Alabaster, T.: 1999, 'Citizen 2000: Development of a model of environmental citizenship', Global Environmental Change 9, 25-43.

He, D.: 2003, 'Introduction to the China sustainable energy program's transportation program', Sinosphere Journal 6(1), 13-17.

Heller, T. C. and Shukla, P. R.: 2003, 'Development and climate: Engaging developing countries', in Joseph, E. Aldy et al. (eds.), Beyond Kyoto: Advancing the International Effort against Climate Change, Arlington: Pew Center on Global Climate Change, pp. 111-140.

Ho, E., Ip, M., and Bedford, R.: 2001, 'Transnational Hong Kong Chinese families in the 1990s', New Zealand Journal of Geography 111, 24-31.

Ho, P.: 2001, 'Greening without conflict? Environmentalism, NGOs and civil society in China', Development and Change 32(5), 893-921.

Hobson, K.: 2003, 'Thinking habits into action: The role of knowledge and process in questioning household consumption practices', Local Environment 8(1), 95-112.

Hook, W.: 1996, 'China mustn't copy Western transport', China Daily, 15 October, 4.

Jackson, H. Jr.: 2005, 'Plight of fight or flight: Early man needed stress to survive but it may kill you now', Missoulian, 28 June, 2005, p. C1-2.

Jasanoff, S.: 2001, 'Image and imagination: The formation of global environmental consciousness', in Clark, A. M. and Paul, N. Edwards (eds.), Changing the Atmosphere: Expert Knowledge and Environmental Governance, Cambridge: MIT Press, pp. 309-337.

Kaplan, S.: 2000, 'Human nature and environmentally responsible behavior', Journal of Social Issues 56(3), 491-508.

Kates, R. W.: 2000, 'Population and consumption', Environment 42(3), 10-19.

Keck, M. E. and Sikkink, K. 1998, Activists beyond Borders: Advocacy Networks in International Politics. Ithaca: Cornell University Press.

Kempton, W.: 1993, 'Will public environmental concern lead to action on global warming?" Annual Review of Energy and the Environment 18, 217-245.

Kempton, W., Boster, J. S., and Hartley, J. A.: 1995, Environmental Values in American Culture. Cambridge: MIT Press.

Kilborn, P. T.: 1999, 'No work for a bicycle thief: Children pedal around less', New York Times, 7 June, p. Al.

Koehn, P. H.: 1999, 'Greasing the grassroots: The role of nongovernmental linkages in the looming U.S.-China confrontation over global petroleum reserves', in Peter, H. Koehn and Joseph, Y.S. Cheng (eds.), The Outlook for U.S.-China Relations Following the 1997-1998 Summits: Chinese and American Perspectives on Security, Trade, and Cultural Exchange, Hong Kong: Chinese University Press, pp. 351-390. 
Koehn, P. H.: 2002, 'The role of cross-nationally competent Chinese + Americans in environmentalinterdependence challenges: Potential and prospects', in Peter H. Koehn and Xiao-huang Yin (eds.), The Expanding Roles of Chinese Americans in U.S.-China Relations: Transnational Networks and Trans-Pacific Interactions, Armonk: M.E. Sharpe, pp. 235-283.

Koehn, P. H.: 2004a, 'Global politics and multinational health-care encounters: Assessing the role of transnational competence', EcoHealth 1(1), 69-85.

Koehn, P. H.: 2004b, 'Sustainable-development frontiers and divides: Transnational actors and U.S./China greenhouse-gas emissions', International Journal of Sustainable Development and World Ecology 11(4), 380-396.

Koehn, P. H.: forthcoming, 'Global climatic stabilization: Challenges for public administration in China and the United States', in Ali Farazmand and Jack Pinkowski (eds.), Handbook of Globalization, Governance, and Public Administration, New York: Marcel Dekker, pp. 10831129.

Koehn, P. H. and Rosenau, J. N.: 2002, 'Transnational competence in an emergent epoch', International Studies Perspectives 3, 105-127.

Koehn, P. H. and Yin, Xiao-huang.: 2002, 'Chinese American transnationalism and U.S.-China relations: Presence and promise for the trans-pacific century', in Peter, H. K. and Xiao-huang Yin (eds.), The Expanding Roles of Chinese Americans in U.S.-China Relations: Transnational Networks and Trans-Pacific Interactions, Armonk: M.E. Sharpe, pp. xi-xl.

Kroeze, C., Vlasblom, J., Gupta, J., Boudri, C., and Blok, K.: 2004, 'The power sector in China and India: Greenhouse gas emissions reduction potential and scenarios for 1990-2020', Energy Policy 31(1), 55-76.

Kull, S.: 2005, Americans on Climate Change: [5 July] 2005. PIPA/Knowledge Networks Poll. www.pipa.org

Kunzli, N., et al.: 2000, 'Public-health impact of outdoor and traffic-related air pollution: A European assessment', Lancet 356(9232), 795-801.

Lai, Chuk-ling, J., Brennan, A., Chan, H., and Tao, J.: 2003, 'Disposition toward environmental hazards in Hong Kong Chinese: Validation of a Chinese version of the environmental appraisal inventory (EAI-C)', Journal of Environmental Psychology 23, 369-384.

Levitt, P.: 2001, The Transnational Villagers. Berkeley: University of California Press.

Li, S.: 2002, 'Navigating U.S.-China waters: The experience of Chinese students and professionals in science, technology, and business', in Peter H. Koehn, and Xiao-huang Yin (eds.), The Expanding Roles of Chinese Americans in U.S.-China Relations: Transnational Networks and Trans-Pacific Interactions, Armonk: M.E. Sharpe, pp. 20-35.

Li, W.: 1999, 'Building ethnoburbia: The emergence and manifestation of the Chinese Ethnoburb in Los Angeles' San Gabriel Valley', Journal of Asian American Studies 2(1), 1-28.

Liang, S.: 2003, 'Walking the tightrope: Civil society organizations in China', China Rights Forum 3, $11-15$

Lien, P.: 2003, 'What do Chinese Americans think and act politically? Results from the multisite Asian American political survey', Paper Presented at the Second International Conference of Institutes and Libraries for Chinese Overseas Studies, Chinese University of Hong Kong, 13-15 March.

Lipschutz, R. D.: 1997, 'Networks of knowledge and practice: Global civil society and protection of the global environment', in L. Anathea Brooks and Stacy D. VanDeveer (eds.), Saving the Seas: Values, Scientists, and International Governance, College Park: University of Maryland Press. pp. 427-468.

Lipschutz, R. D. and Mayer, J.: 1996, Global Civil Society and Global Environmental Governance: The Politics of Nature from Place to Planet. Albany: State University of New York Press.

Litfin, K. T.: 1999, 'Constructing environmental security and ecological interdependence', Global Governance 5(3), 359-377. 
Liu, H.: 2002, 'Historical connections between the Chinese transPacific family and U.S.-China relations', in Peter H. Koehn and Xiao-huang Yin (eds.), The Expanding Roles of Chinese Americans in U.S.-China Relations: Transnational Networks and Trans-Pacific Interactions, Armonk: M.E. Sharpe. pp. 3-19.

Liu, H.: 1998, 'Old linkages, new networks: Globalization of overseas Chinese voluntary associations and its implications', China Quarterly 155, 582-609.

Lo, C. W. H. and Leung, S. W.: 2000, 'Environmental agency and public opinion in Guangzhou: The limits of a popular approach to environmental governance', China Quarterly 163, 677-704.

London, J. B., Li, J., Ward, W. A., Wells, G. J., Dai, Y. and Liu, J.: 1998, 'Options for reducing greenhouse gas emissions in the Chinese industrial sector', Energy Policy 26(6), 477-485.

Lowe, M. D.: 1989, The Bicycle: Vehicle for a Small Planet. Worldwatch Paper 90. Washington, D.C.: Worldwatch Institute.

Lu, H.: 2000, 'To be relatively comfortable in an egalitarian society', in Deborah S. Davis (ed.), The Consumer Revolution in Urban China, Berkeley: University of California Press, pp. 124-141.

Lu, H.: 2003, 'Bamboo sprouts after the rain: The history of university student environmental associations in China', China Environment Series 6, 55-66.

Lun, J.: 2003, 'An update on efforts to promote cleaner vehicles in China', Sinosphere Journal 6(1), $28-33$.

Lutzenhiser, L.: 1997, 'Social structure, culture, and technology: modeling the driving forces of household energy consumption', in Paul C. Stern, Thomas Dietz, Vernon W. Ruttan, Robert H. Socolow, and James J. Sweeney (eds.), Environmentally Significant Consumption: Research Directions, Washington, D.C.: National Academy Press. pp. 77-91.

Macnaghten, P. and Jacobs, M.: 1997, 'Public identification with sustainable development', Global Environmental Change 7(1), 5-24.

Madsen, R.: 1995. China and the American Dream: A Moral Inquiry. Berkeley: University of California Press.

Madsen, R.: 2000, 'Epilogue: The second liberation', in Deborah S. Davis (ed.),The Consumer Revolution in Urban China, Berkeley: University of California Press, pp. 312-319.

Maniates, M.: 2002a, 'Individualization: Plant a tree, buy a bike, save the world?' in Thomas Princen, Michael Manatiates and Ken Conca (eds.), Confronting Consumption, Cambridge: MIT Press, pp. 43-66.

Maniates, M.: 2002b, 'In search of consumptive resistance: The voluntary simplicity movement', in Thomas Princen, Michael Manatiates, and Ken Conca (eds.), Confronting Consumption, Cambridge: MIT Press. pp. 199-235.

Manning, R. A.: 2000. The Asian Energy Factor: Myths and Dilemmas of Energy, Security and the Pacific Future. New York: Palgrave.

Manno, J. 2002, 'Commoditization: Consumption efficiency and an economy of care and connection', in Thomas Princen, Michael Manatiates, and Ken Conca (eds.), Confronting Consumption, Cambridge: MIT Press, pp. 67-99.

Mao, B. and Chen, H.: 2001, 'Sustainability analysis of Chinese transport policy', International Journal of Sustainable Development and World Ecology 8(4), 323-336.

Mayell, H.: 2004, 'As consumerism spreads, Earth suffers, study says', National Geographic News, 12 January. http://news.nationalgeographic.com.news/2004/01/0111 040112 consumerism.html

McDonald, M.: 2005, 'Fair weather friend? Ethics and Australia's approach to global climate change', Australian Journal of Politics and History 51(2), 216-234.

McMurray, S. and Smith, R.: 2001,Diseases of Globalization: Socioeconomic Transitions and Health, London: Earthscan.

McQueen, D. V., McKenna, M. T. and Sleet, D. A.: 2001, 'Chronic diseases and injury', in Michael H. Merson, Robert E. Black, and Anne J. Mills (eds.), International Public Health: Diseases, Programs, Systems, and Policies, Gaithersburg: Aspen Publishers. pp. 293-330. 
Miller, T.: 1995, How to Want What You Have, New York: Harper Audio.

Molloy, T.: 2004, 'Regulators approve world's toughest vehicle smog rules', Missoulian 25 September, A2.

Murphy, J.: 2001, 'From production to consumption: Environmental policy in the European Union', in Maurie J. Cohen and Joseph M. Murphy (eds.), Exploring Sustainable Consumption: Environmental Policy and the Social Sciences, vol. 1, Amsterdam: Pergamon, pp. 39-58.

Murphy, J. and Cohen, M. J.: 2001, 'Sustainable consumption: Environmental policy and the social sciences', in Maurie J. Cohen and Joseph M. Murphy (eds.), Exploring Sustainable Consumption: Environmental Policy and the Social Sciences, vol. 1, Amsterdam: Pergamon, 225-240.

Myers, N.: 1997, 'Consumption: Challenge to sustainable development', Science 276(5309), 53-55.

Nakicenovic, N. et al.: 2000. Emissions Scenarios: A Special Report of Working Group III of the Intergovernmental Panel on Climate Change, Cambridge: Cambridge University Press.

Nielsen, C. P. and McElroy, M. B.: 1998, 'Introduction and overview', in Michael B. McElroy, Chris P. Nielsen, and Peter Lydon (eds.), Energizing China: Reconciling Environmental Protection and Economic Growth, Cambridge: Harvard University Press, pp. 1-63.

Nordlund, A. M. and Garvill, J.: 2003, 'Effects of values, problem awareness, and personal norm on willingness to reduce personal car use', Journal of Environmental Psychology 23, 339-347.

O'Brien, M.: 1995, 'Introduction', in Yvonne Guerrier, Nicholas Alexander, Jonathan Chase, and Martin O'Brien (eds.), Values and the Environment: A Social Science Perspective, Chichester: John Wiley \& Sons, pp. 167-170.

Ogden, D. and Fong, P.: 2002, 'The China sustainable development program: An overview', Sinosphere Journal 5(1), 6-9.

Oksenberg, M. and Economy, E.: 1998, 'China: Implementation under economic growth and market reform', in Edith B. Weiss and Harold K. Jacobson (eds.), Engaging Countries: Strengthening Compliance with International Environmental Accords, Cambridge: MIT Press. pp. 353394.

Ophuls, W. and Boyan, S. A.: 1992. Ecology and the Politics of Scarcity Revisited: The Unraveling of the American Dream. New York: W., H. Freeman.

O'Riordan, T. and Jager, J.: 1996, 'Beyond climate change science and politics.' in Tim O'Riordan and Jill Jager (eds.), Politics of Climate Change: A European Perspective, London: Routledge. pp. 346-360.

O'Riordan, T. and Jordan, A.: 1996, 'Social institutions and climate change', in Tim O'Riordan and Jill Jager (eds.), Politics of Climate Change: A European Perspective, London: Routledge, pp. 65-105.

Paterson, M.: 1996, 'IR theory: Neorealism, neoinstitutionalism and the climate change convention', in John Vogler and Mark F. Imber (eds.), The Environment and International Relations, London: Routledge, pp. 59-76.

Paterson, M.: 2000, 'Car culture and global environmental politics', Review of International Studies 26, 253-270.

Peng, D.: 2002, 'Invisible linkages: A regional perspective of East Asian political economy', International Studies Quarterly 46(3), 423-447.

Potter, S.: 2001, 'Summing up the technology factor', Town \& Country Planning, 139-142.

Princen, T.: 2002, 'Consumption and its externalities: Where economy meets ecology,' in Thomas Princen, Michael Manatiates, and Ken Conca (eds.), Confronting Consumption, Cambridge: MIT Press, pp. 23-42.

Princen, T.: 2003, 'Principles for sustainability: From cooperation and efficiency to sufficiency.' Global Environmental Politics 3(1), 33-50.

Princen, T., Maniates, M., and Conca, K.: 2002, 'Confronting consumption', in Thomas Princen, Michael Manatiates, and Ken Conca (eds.), Confronting Consumption, Cambridge: MIT Press, pp. 1-20. 
Qian, J., Finamore, B., and Clegg, T.: 2003, 'Fuel cell vehicle development in China', Sinosphere Journal 6(1), 34-40.

Ray, C.: 2002, 'Cultural paradigms and challenges: An anthropological perspective on climate change', in Sharon L. Spray and Karen L. McGlothin (eds.), Global Climate Change, Lanham: Rowman \& Littlefield, pp. 81-100.

Redclift, M. R.: 1995, 'Values and global environmental change', in Yvonne Guerrier, Nicholas Alexander, Jonathan Chase, and Martin O'Brien (eds.), Values and the Environment: A Social Science Perspective, Chichester: John Wiley \& Sons, pp. 7-17.

Revkin, A. C.: 2001, 'Bush's shift could doom air pact, some say', New York Times 17 March, A7.

Revkin, A. C.: 2004, 'NASA expert criticizes Bush on global warming policy', New York Times 26 October, A20

Revkin, A. C.: 2005, 'Top-level editing on climate issues', New York Times 8 June, A1, A16.

Roberts, P.: 2004. The End of Oil: On the Edge of a Perilous New World. Boston: Houghton Mifflin.

Rosenau, J. N.: 1997a. Along the Domestic-foreign Frontier: Exploring Governance in a Turbulent World. Cambridge: Cambridge University Press.

Rosenau, J. N.: 1997b, 'Enlarged citizen skills and enclosed coastal seas', in L. Anathea Brooks and Stacy D. VanDeveer (eds.), Saving the Seas: Values, Scientists, and International Governance, College Park: University of Maryland Press. pp. 329-355.

Rosenau, J. N.: 2003. Distant Proximities: Dynamics beyond Globalization. Princeton: Princeton University Press.

Ross, L.: 1998, 'China: Environmental protection, domestic policy trends, patterns of participation in regimes and compliance with international norms', China Quarterly 156, 809-835.

Sanders, E.: 2005, 'Rebuffing Bush, 132 mayors embrace Kyoto rules', New York Times 14 May, p. A8.

Schipper, L., Bartlett, S., Hawk, D. and Vine, E.: 1989, 'Linking life-styles and energy use: A matter of time?' Annual Review of Energy 14, 273-320.

Schor, J. B.: 1998, The Overspent American: Upscaling, Downshifting, and the New Consumer. New York: Basic Books.

Schultz, P. W., Oskamp, S., and Mainieri, T.: 1995, 'Who recycles and when? a review of personal and situational factors', Journal of Environmental Psychology 15, 105-121.

Shanahan, H. and Carlsson-Kanyama, A.: 2005, 'Interdependence between consumption in the North and sustainable communities in the South', International Journal of Consumer Studies 29(4), 298-307.

Shen, Q.: 1997, 'Urban transportation in Shanghai: Problems and planning implications', International Journal of Urban and Regional Research 21(4), 589-606.

Sinton, J. E. and Fridley, D. G.: 2003, 'Comments on recent energy statistics from China', http./eetd.lbl.gov/EA/partnership/China/pubs

Sklair, L.: 1994, 'The culture-ideology of consumerism in Urban China: Some findings from a survey in Shanghai', Research in Consumer Behavior 7, 259-292.

Skeldon, R.: 1997, 'Of migration, great cities, and markets: Global systems of development', in Wang, G., (ed.), Global History and Migrations, Boulder: Westview Press. pp 183-215.

Sperling, D. and Salon, D.: 2002, Transportation in Developing Countries: An Overview of Greenhouse Gas Reduction Strategies. Arlington: Pew Center on Global Climate Change.

Spray, S. L. and McGlothlin, K. L.: 2002, 'The long road ahead: Concluding thoughts on climate change', in Sharon L. Spray and Karen L. McGlothin (eds.), Global Climate Change, Lanham: Rowman \& Littlefield. pp. 145-156.

Steinberg, P. F.: 2001. Environmental Leadership in Developing Countries: Transnational Relations and Biodiversity Policy in Costa Rica and Bolivia. Cambridge: MIT Press.

Steinberg, P. F.: 2003, 'Understanding policy change in developing countries: The spheres of influence framework', Global Environmental Politics 3(1), 11-32. 
Stengle, J.: 2004, 'Obesity is rising sharply among U.S. preschoolers', Missoulian 31 December, p. A4.

Stern, P. C.: 1997, 'Toward a working definition of consumption for environmental research and policy', in Paul C. Stern, Thomas Dietz, Vernon W. Ruttan, Robert H. Socolow and James J. Sweeney (eds.), Environmentally Significant Consumption: Research Directions, Washington, D.C.: National Academy Press, pp. 12-25.

Stern, P. C.: 2000, 'Toward a coherent theory of environmentally significant behavior', Journal of Social Issue 56(3), 407-424.

Stern, P. C. and Dietz, T.: 1994, 'The value basis of environmental concern', Journal of Social Issues 50(3), 65-84.

Stern, P. C., Dietz, T. and Kalof, L.: 1993, 'Value orientations, gender, and environmental concern', Environment and Behavior 25, 322-348.

Stern, P. C., Dietz, T., Ruttan, V. W., Socolow, R. H. and Sweeney, J. L.: 1997, 'Strategies for setting research priorities', in Paul C. Stern, Thomas Dietz, Vernon W. Ruttan, Robert H. Socolow and James J. Sweeney (eds.), Environmentally Significant Consumption: Research Directions pp.

Stern, P. C., Ruttan, V. W., Socalow, R. H. and Sweeney, J. J. Washington, D. C.: National Academy Press, pp. 124-137.

Stockholm Environment Institute.: 2002, China Human Development Report 2002: Making Green Development a Choice, Oxford: Oxford University Press.

Stoll-Kleemann, S., O'Riordan, T. and Jaeger, C. C.: 2001, 'The psychology of denial concerning climate mitigation measures: Evidence from Swiss focus groups', Global Environmental Change 11, 107-117.

Stone, R.: 1993, 'The Chinese-American connection', Science 262 (5132), pp. 350.

Tanner, C.: 1999, 'Constraints on environmental behaviour', Journal of Environmental Psychology 19, 145-157.

Tatum, J.: 2002, 'Citizens or consumers: The home power movement as a new practice of technology', in Thomas Princen, Michael Manatiates, and Ken Conca (eds.), Confronting Consumption, Cambridge: MIT Press. pp. 301-315.

Tu, W.: 1991, 'Cultural China: The periphery as the center', Daedalus 120, 1-32.

Tusiani, Michael D.: 2004, 'Gas gluttony near end', Missoluian 29 April, p. A8.

United States, Department of Energy, Energy Information Administration, 2002. 'International energy related environmental information', 12 December http://www.eia.doe.gov/emeu/international/ environm.htm.

United States, Department of Energy, Energy Information Administration (EIA) 2004, 'International energy outlook 2004', www.eia.doc.gov/oiaf/ieo.

Uzzell, D. L.: 2000, 'The psycho-spatial dimension of global environmental problems', Journal of Environmental Psychology 20, 307-318.

Verba, S.: 2003, 'Would the dream of political equality turn out to be a nightmare?' Perspectives on Politics 1(4), 663-670.

Vertovec, S.: 2003, 'Migration and other modes of transnationalism', International Migration Review 37(3), 641-665.

Vincent, J. R. and Panayotou, T.: 1997, ‘. . .or Distraction?', Science 276(5309), 55-56.

Walsh, M. P.: 1989, 'The global importance of motor vehicles in the climate modification problem', International Environmental Reporter, pp. 261-267.

Wang, Z.: 2002, 'Chinese American scientists and U.S.-China scientific relations: From Richard Nixon to Wen Ho Lee', in Peter H. Koehn and Xiao-huang Yin (eds.), The Expanding Roles of Chinese Americans in U.S.-China Relations: Transnational Networks and Trans-Pacific Interactions, Armonk: M.E. Sharpe. pp. 207-234.

Wapner, P.: 1998, 'Reorienting state sovereignty: Rights and responsibilities in the environmental age', in Karen, T. Litfin (ed.), The Greening of Sovereignty in World Politics, Cambridge: MIT Press. pp. 275-297. 
Watanabe, P. Y.: 2001, 'Building on the indigenous base: The fund-raising controversy and the future of Asian American political participation', in Gordon H. Chang (ed.), Asian Americans and Politics: Perspectives, Experiences, and Prospects, Washington, D.C.: Woodrow Wilson Center Press, pp. 367-382.

Weller, R. P. and Bol, P.: 1998, 'From heaven-and-earth to nature: Chinese concepts of the environment and their influence on policy implementation', in Michael B. McElroy, Chris P. Nielsen, and Peter Lydon (eds.), Energizing China: Reconciling Environmental Protection and Economic Growth, Cambridge: Harvard University Press. pp. 473-499.

Werner, C. M. and Makela, E.: 1998, 'Motivations and behaviors that support recycling', Journal of Environmental Psychology 18, 373-386.

Wilk, R.: 1998, 'Emulation, imitation, and global consumerism', Organization \& Environment 11(3), 314-333.

Winter, D. D.: 1996. Ecological Psychology: Healing the Split between Planet and Self, New York: HarperCollins.

Wu, F.: 2002, 'New partners or old brothers? GONGOs in transnational environmental advocacy in China', China Environment Series 5, 45-58.

Yang, G.: 2003a, 'China's Zhiqing generation: Nostalgia, identity, and cultural resistance in the 1990s', Modern China 29(3), 267-296.

Yang, G.: 2003b, 'Weaving a green web: The internet and environmental activism in China', China Environment Series 6, 89-93.

Yang, P. Q. 1999, 'Sojourners or settlers: Post-1965 Chinese immigrants', Journal of Asian American Studies 2(1), 72-86.

Yeh, Emily, T.: 2004, 'Thinking about globalization and China's environment: The case of Western China', Paper presented at the 20th Annual Mansfield Conference, "The Complex Face of Globalization in China," University of Montana, Missoula, 20 April.

Yi, X.: 2002, 'Win-win strategy: Two giants' challenge, responsibility and cooperation in addressing climate change', Unpublished paper, Division of Environmental and Polar Affairs, Ministry of Foreign Affairs, Beijing.

Yin, X.: 1999, 'The growing influence of Chinese Americans on U.S.-China relations', in Peter H. Koehn and Joseph Y.S. Cheng (eds.), The Outlook for U.S.-China Relations Following the 19971998 Summits: Chinese and American Perspectives on Security, Trade, and Cultural Exchange, Hong Kong: Chinese University Press, pp. 331-349.

Yin, X.: 2005, 'Changes and continuity in Chinese American philanthropy to China: A case study of Chinese American transnationalism', Journal of American Studies 45(2).

Zavestoski, S.: 2001, 'Environmental concern and anti-consumerism in the self-concept: Do they share the same basis?", in Maurie J. Cohen and Joseph M. Murphy (eds.), Exploring Sustainable Consumption: Environmental Policy and the Social Sciences, vol. 1, Amsterdam: Pergamon. pp. 173-189.

Zhang, Z.: 2000, 'Decoupling China's carbon emissions increase from economic growth: An economic analysis and policy implications', World Development 28(4), 739-752.

Zhao, J. and Gallagher, K. S.: 2003, 'Clean vehicle development in China', Sinosphere Journal 6(1), $20-28$.

Zhou, H., Sperling, D., Delucchi, M. and Salon, D.: 2001. Transportation in Developing Countries: Greenhouse Gas Scenarios for Shanghai, China, Arlington: Pew Center on Global Climate Change.

(Received 23 July 2003; in revised form 10 November 2005) 